تخمين دادههاى گمشده بارش و رواناب روزانه با استفاده از نخاشت

خودسامانده (مطالعه موردى استان مازندران)

ساناز اسلامى جمال آباد'، احمد شرافتى '، عمادالدين محمدى گل افثانى' و فرهاد فرسادنيا'

(تاريخ دريافت: س/ / /

جكيده

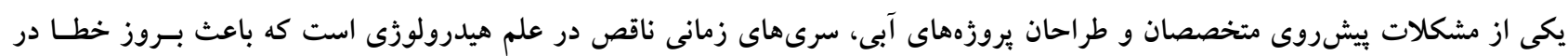

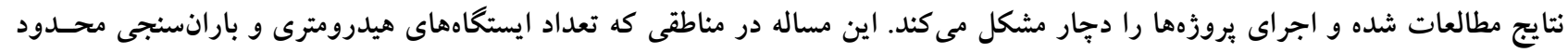

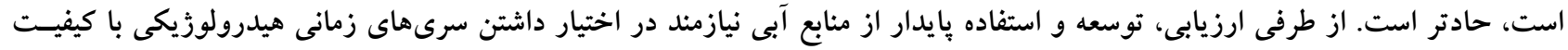

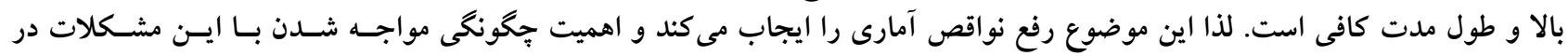

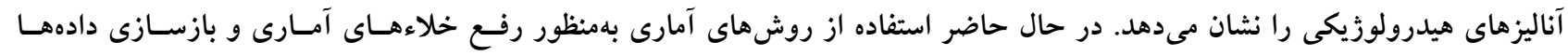

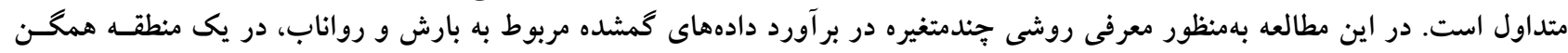

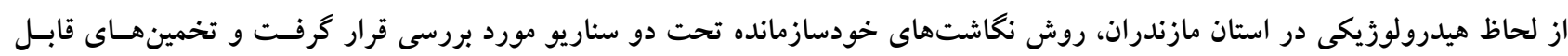

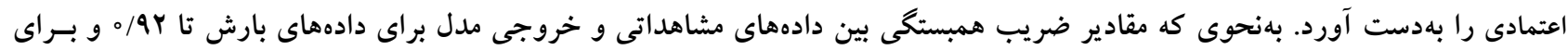

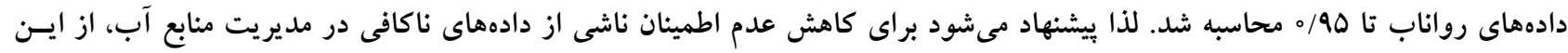

روش استفاده شود.

وازههاى كليدى: شبكهعصبى غيرنظارت شونده، بازسازى سرىهاى زمانى، دادههاى گمشده

ا. كروه مديريت ساخت و آب، واحد علوم و تحقيقات، دانشخاه آزاد اسلامى تهران، ايران

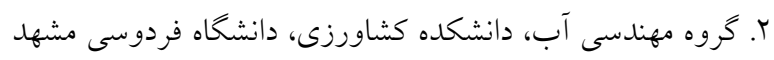

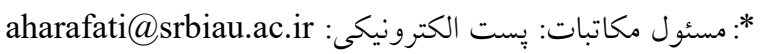


ميانخين گيرى حسابى مورد استفاده قرار مى گيرد (ما و س ب) و يا

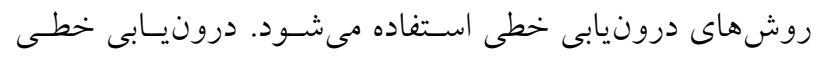

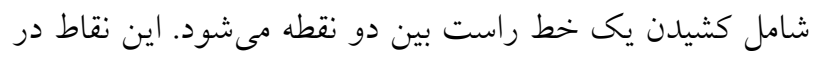

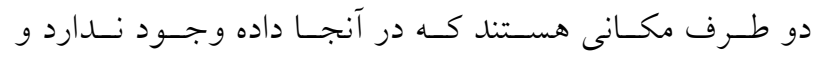
درونيابى توسط اين خط مستقيم صورت مى گيرد.

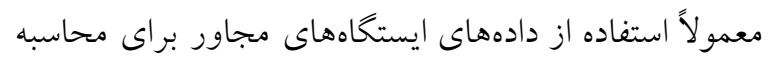

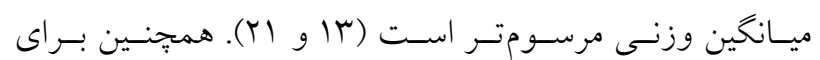
محاسبه ركرسيون خطى نيز از داده هاى ايستـاه هـاى مجـاور استفاده مى شود (r و 9 9). فاكتور وزن ممكـن اسـت از ضـريب

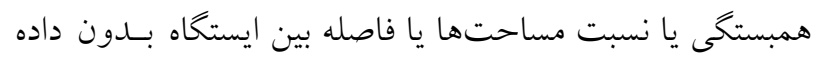

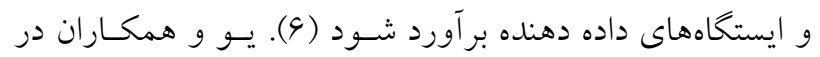

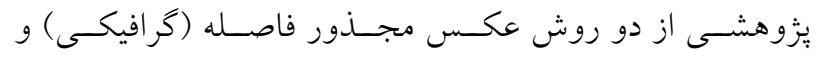

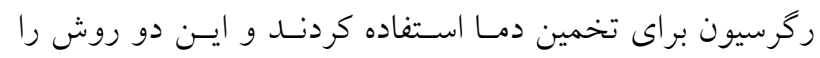

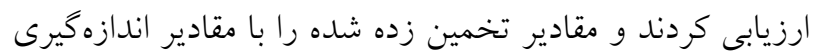

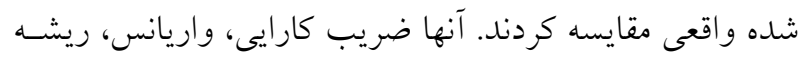

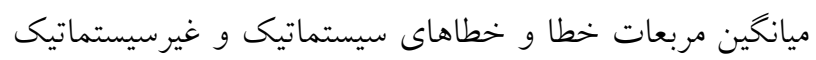

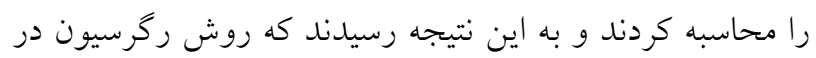
نواحى كوهستانى مناسبتر از عكس مجذور فاصله است و نيـز

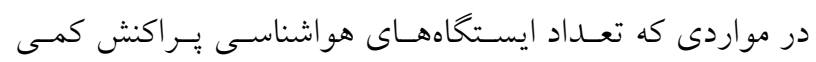

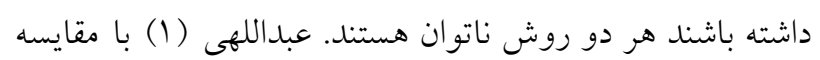

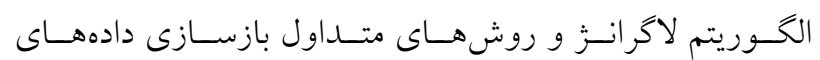

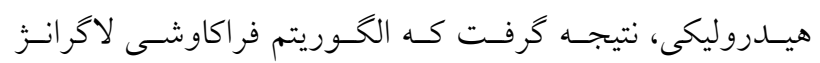

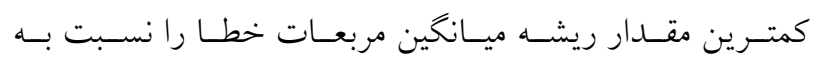

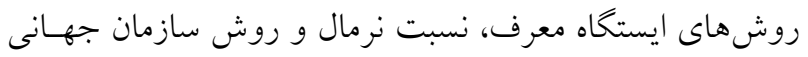
هو اشناسـى دارا اسـت و مقــادير بازسـازى شـــهـ بـهـ مقــادير مشاهداتى نزديكتر است. اكر جهه بيشتر روشهاى سنتى سادهسازى را بيشنهاد مى كنند

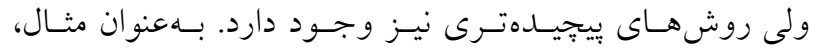
ساداتىنزاد (Yq) در مقايسه آمارى روشهاى مختلف بازسـازى دادههاى بارش سالانه در استان اصفهان بهمنظور تعيسين بهتـرين روش در هر اقليم، هفت روش بازسازى شامل ايستخاه معـرف، نسبت نرمال، محور مختصاتى، رگرسيون خطى ساده، رگرسيون

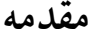

اساس و هِايه مطالعات هيدرولوزىى، دادههاى آمارى مورد قبـول است. با توجه به خلأهاى گسسته و وييوسته در اغلـب دادههـاى

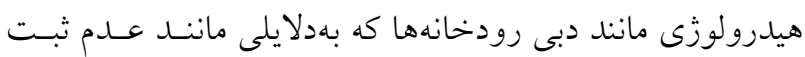

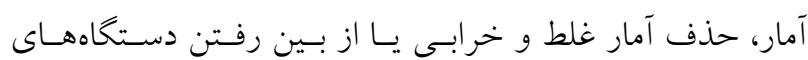

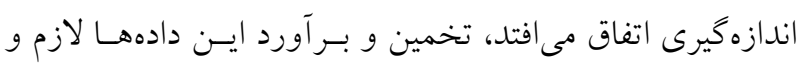

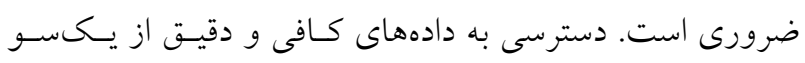

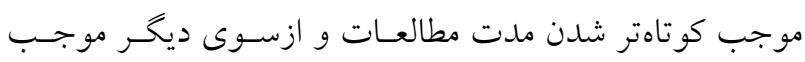

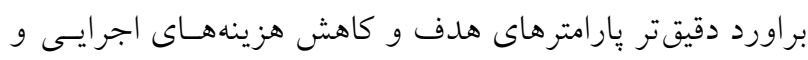

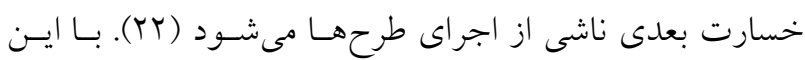

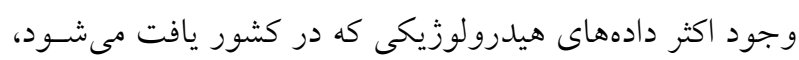

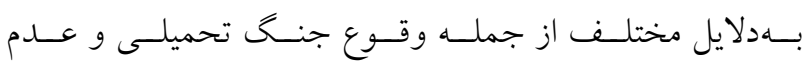

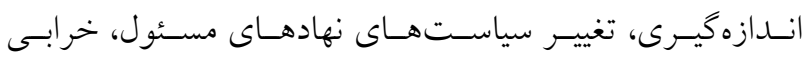

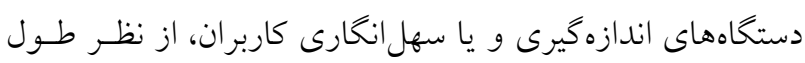

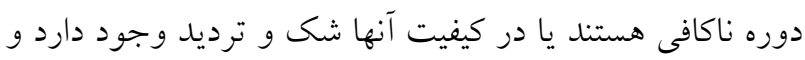

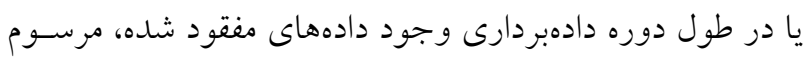

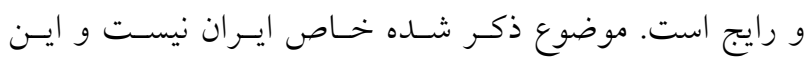

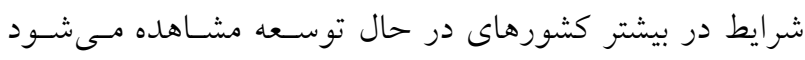

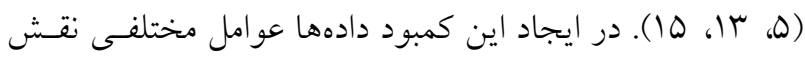
دارند، مانند غيبت موقت مسـئول دادهبـردارى، خرابـى وسـايل

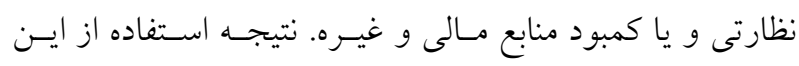

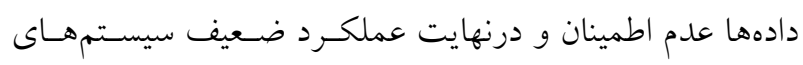
مديريت منابع آب خواهد بود (آو ه ه). برخى روشهاى تخمين دادهاى گم شده به تعداد دادههاى

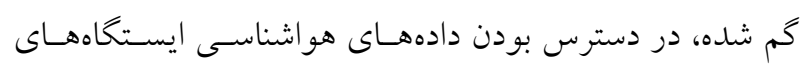

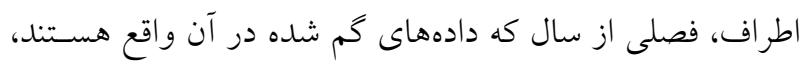

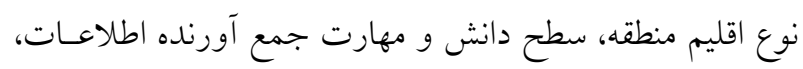

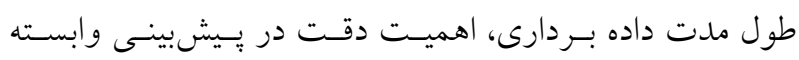

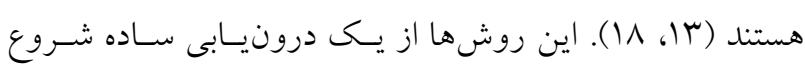

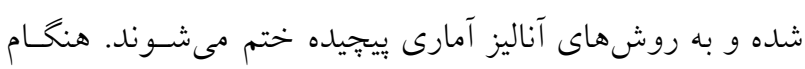

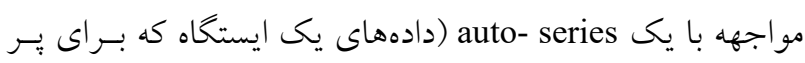

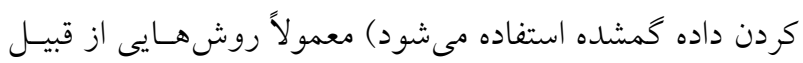


شده هيدرولوزى ارزيابى كرد. به اين منظـور، نتسايج حاصل از

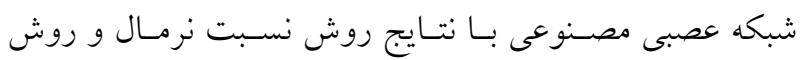

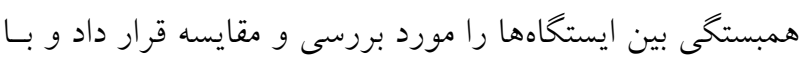

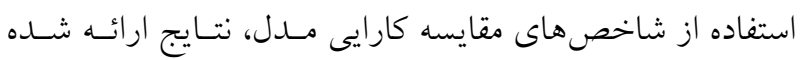
توسط هر يك از روشها را با مقادير مشـاهداتى مقايسـه كـرد.

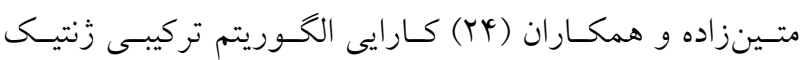
عصبى مصنوعى در بازسازى دادهاى حداكثر بارش با سـاعته در استان جهار محال و بختيارى را مـورد ارزيـابى قــرار دادنـــ.

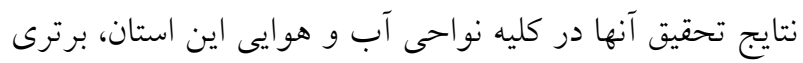

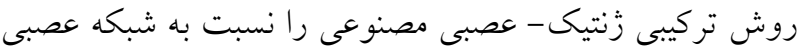

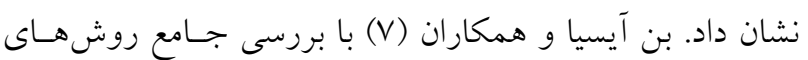
مختلف تكى متغيره و جندمتغيره در بازسـازى دادههـاى مفقـود هيدرولوزيكى، با استفاده از روش جكى- نايف نشان دادنــ كـهـ كاربرد روشهاى جندمتغيره، در مقايسه با روشهاى جايكزينى و روشهاى درونيابى، موجب بهبـود عملكـرد و بهبـود نتسايج مى شود. الحسوريتم نحاشـت خودسـامانده (Self- Organizing Map)

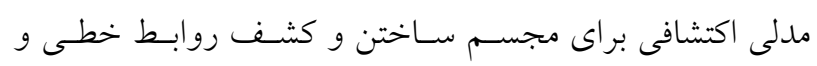

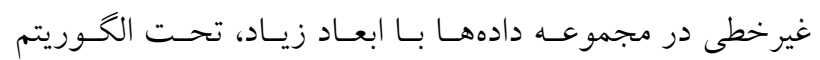

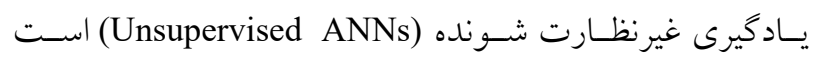
(19). تاكنون SOM در بسيارى از مطالعات هيدرولوزيكى به بكار رفته است. عملكـــد شـبكههـاى عصـبى مصـنوعى نسـبت بـهـ

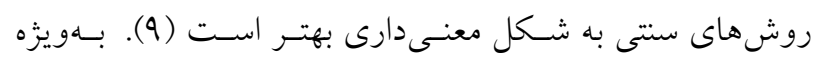
مطالعات اخير نشان دادند كه نگاشتهاى خودسامانده (SOM) كه حالت بدون نظارت شبكههاى عصسبى مصــوعى اسـت، در

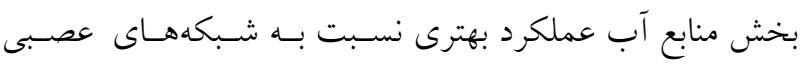

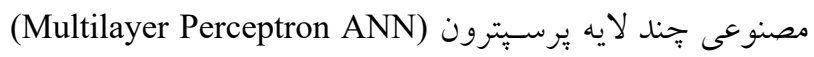
از خود نشان مى دهد (19). همجنين نخاشتهـاى خودسـامانده در طى آموزش بسيار قدرتمندتر از شبكههاى عصبى مصسنوعى

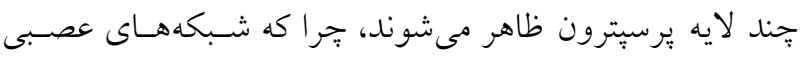

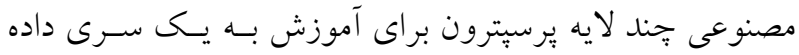

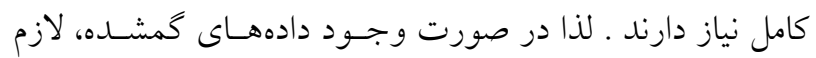

خطى جندمتغيره و اتورگرسيو را مورد بررسى قـرار داد كـه در

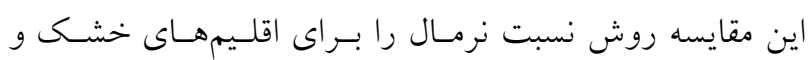

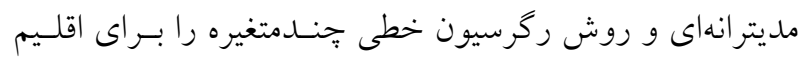

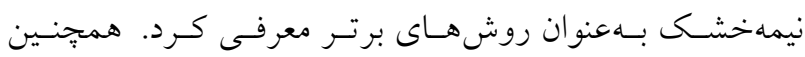

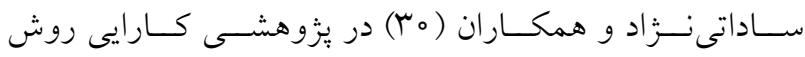

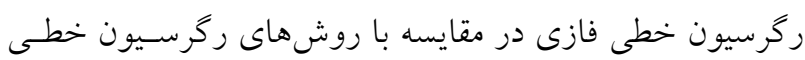

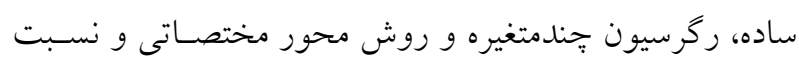

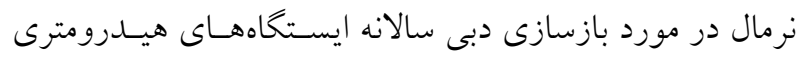

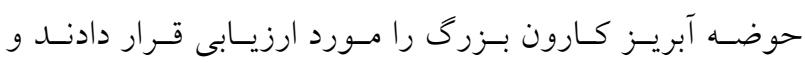

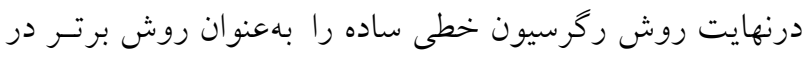

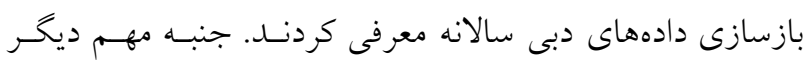

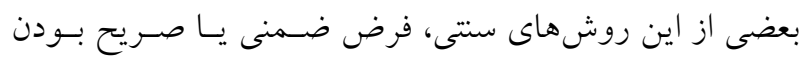

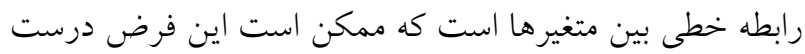

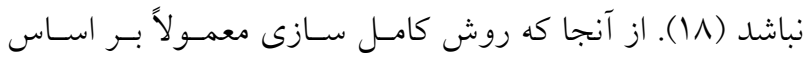
دادههاى ايستخاههاى اطراف است، مشاهده شد زمانى كه فاكتور

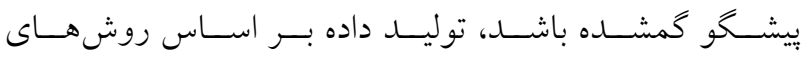

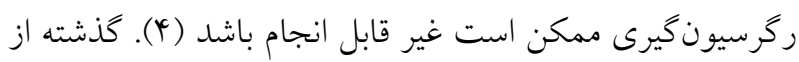

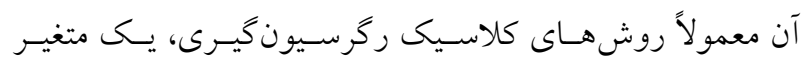

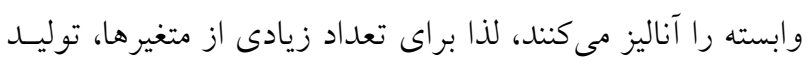

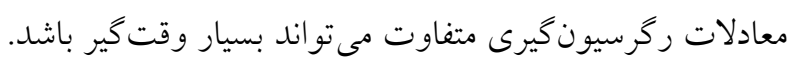

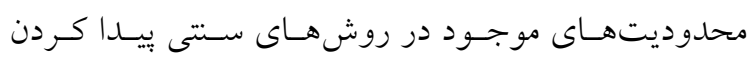

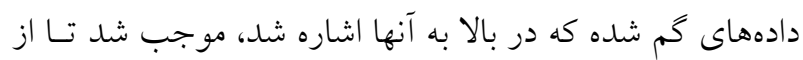
شـبكههـاى عصسبى مصسنوعى (Artificial Neural Network)

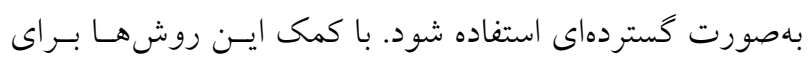

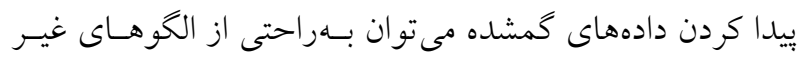

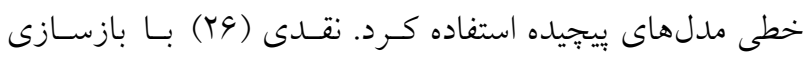

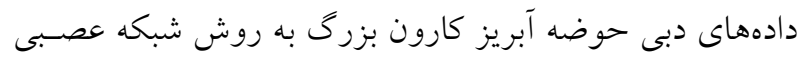

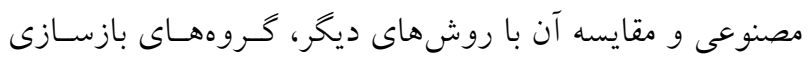

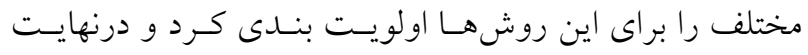

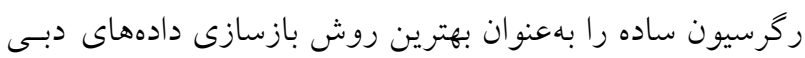

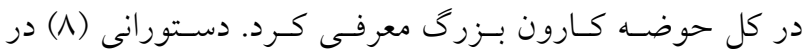
تحقيقى كارايى هوش مصنوعى را در تخمسين دادهــاى مفتـود 


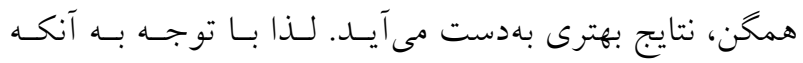

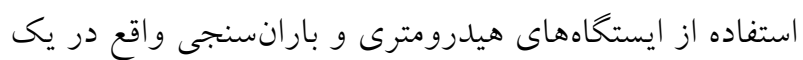

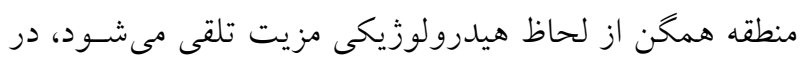

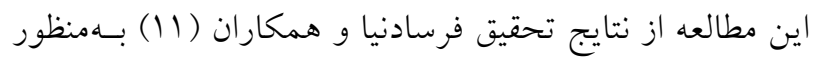

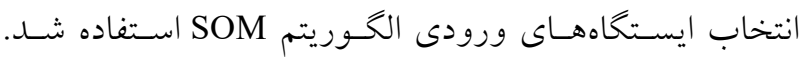

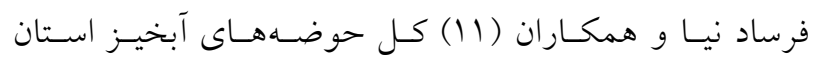

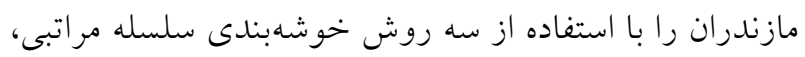

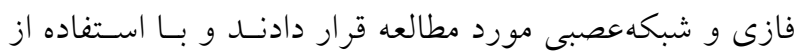

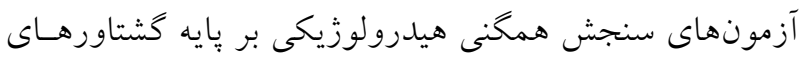

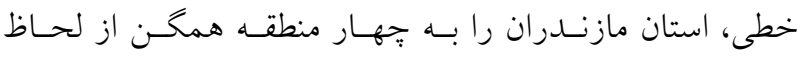
هيــرولوزيكى تقسـيم كردنـــ (شـكل ()). در ايسن مطالعـه از ماز اطلاعات ثبت شده در 11 ايستخاه هيـدرومترى و و 9 ايستخاه بارانسنجى واقع در منطقه همخن شماره جهار استان مازندران (شكل () استفاده شد. اسامى و مشخصات ايستخاههاى مذكور

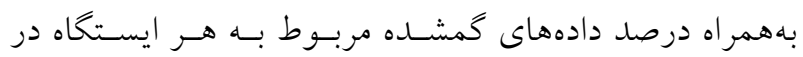
جدول (1) ارائه شده است. بيشتر دادههاى گمشده مربوط بـهـ

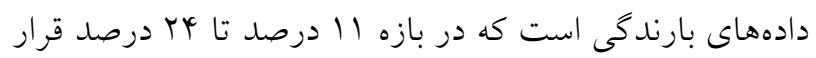

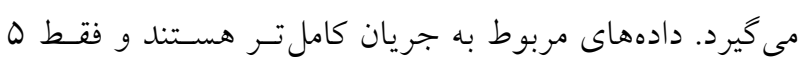

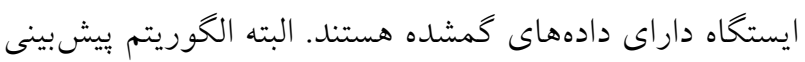

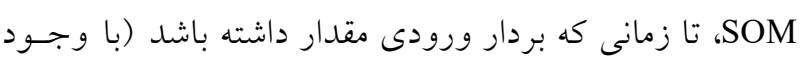

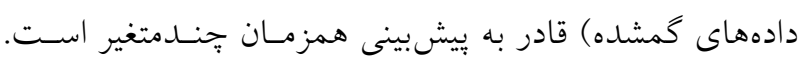

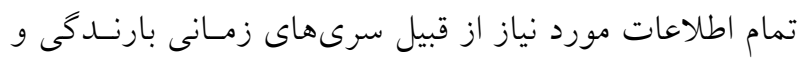

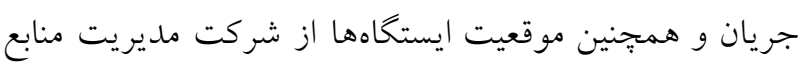

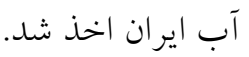

\section{نجاشت خودسامانده (SOM)}

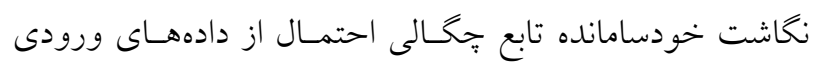
تحت الكوريتم يادگيرى غيرنظارت شونده اســت، كـهـ بـهعنوان روشى مؤثر براى خوشهبندى، خلاصسهـازى و بصـرى كـردن

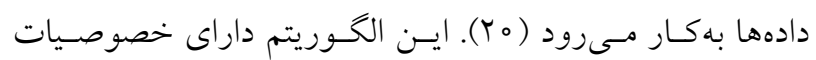

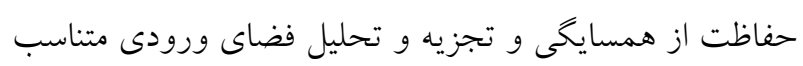

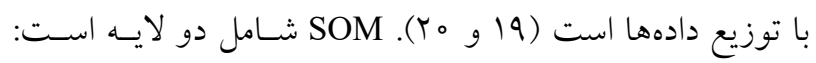

است قبل از آموزش MLP-ANNs تخمينهاى اوليـه در مـورد

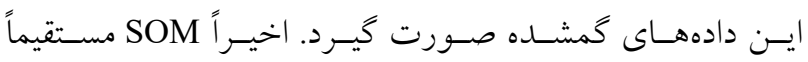

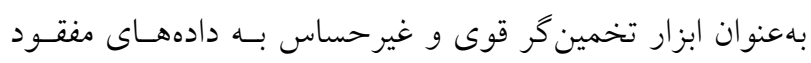
بله كار كرفته شده است. وال و همكاران (TOU) بهمنظور تخمسين دادههـاى مفتـود در

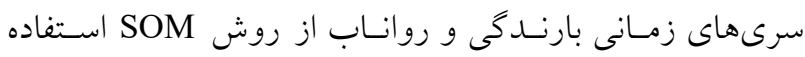

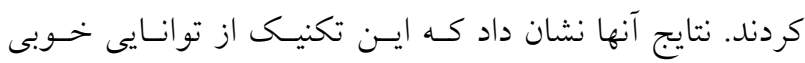

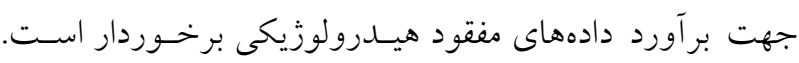

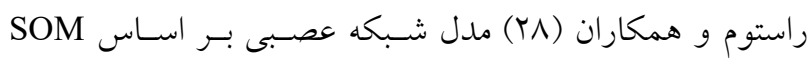
بهمنظور بيشبينى سريع اكسيزن خواهى بيوشسيميايى يـنج روزه

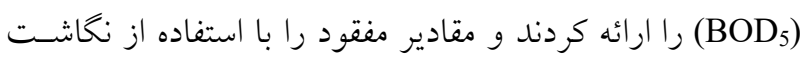

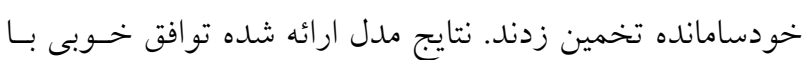
مقادير اندازهيرى شده توسط روش سنتى داشت.

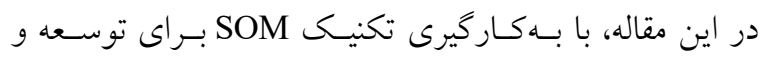

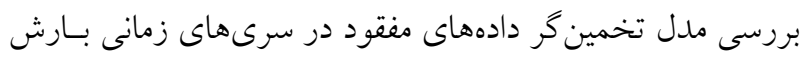

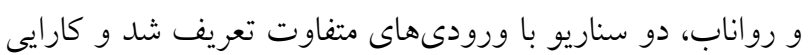
دو سناريو ارائه شده با شاخصهاى ارزيابى، مقايسه شد.

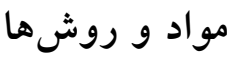

هدف از اين تحقيق دستيابى به يك مدل هوش مصنوعى دقيـق

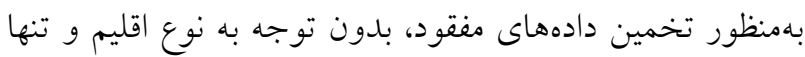
با استفاده از سرىهاى زمانى ناقص است. در ادامه منطقه مـورد

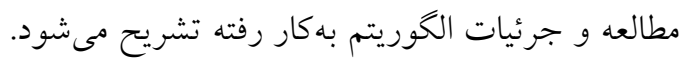

منطقه مورد مطالعه و دادههاى مورد استفاده

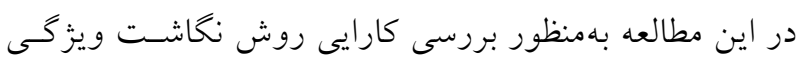

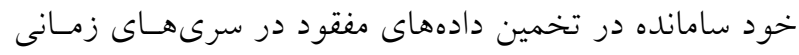

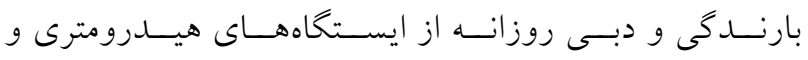
بارانسنجى واقع در يك منطقه همكن از لحاظ هيدرولوزيكى دوري

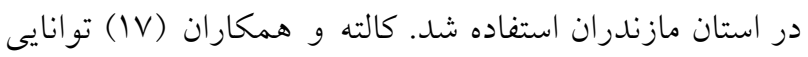

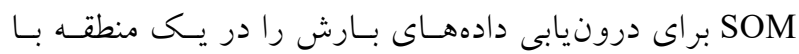

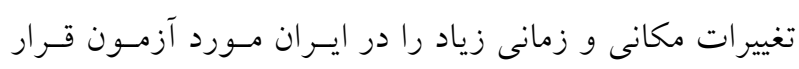

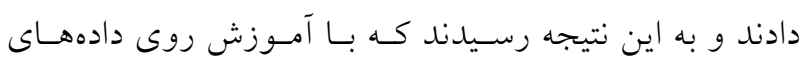




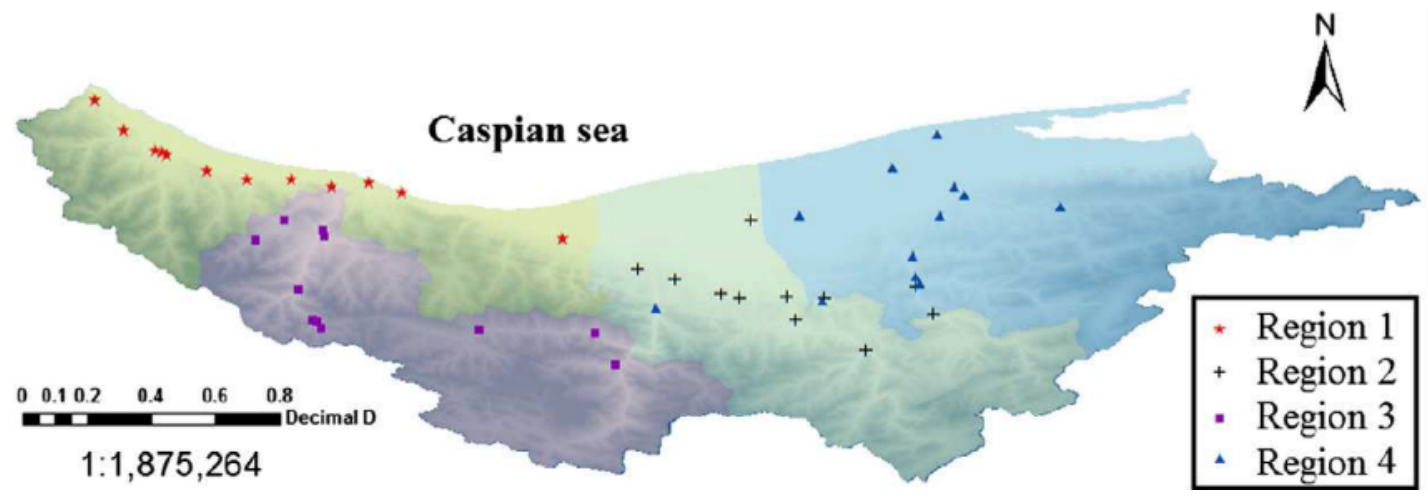

شكل 1. مناطق هيدرولوزيكى همخن استان مازندران (11)

جدول ا. مشخصات ايستخاههاى مورد مطالعه

\begin{tabular}{|c|c|c|c|c|c|c|c|c|}
\hline دادههاى گمشده & 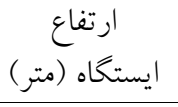 & جغر افيايى (متر) & جغر افيايى (متر) & حوضه & رودخانه & ايستخام & ايستخاه & : \\
\hline $1 T / 0$ & $q \vee \Delta$ & $p \circ p y \circ q r$ & O1901 & سردآبرود & سردآبرود & و والت & $19-010$ & \multirow{11}{*}{ c. } \\
\hline 。 & Ir人。 & FOrVYYQO & $01110 \mathrm{~V}$ & سردآبرود & سردآبرود & كاردشت & سץ-0 19 & \\
\hline 。 & IYYo & Y००Я & $909|\pi|$ & 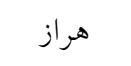 & 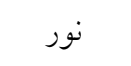 & 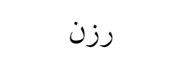 & $10-010$ & \\
\hline$\varphi / \mu$ & $\wedge 9_{0}^{\circ}$ & Ma90Trg & GlYokr & & نمارستاق & ينجاب & $10-011$ & \\
\hline 。 & 1\%9. & 40.99119 & DVRVGG & & 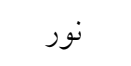 & بلده & $10-0 \mid r$ & \\
\hline$r \mu / 4$ & 1900 & $40 \circ 9 v 90$ & DTAKGY & جالوس & هريجان & دره هريجان & $19-01 \mathrm{~V}$ & \\
\hline 。 & rVo & Y०HMMgq & QH०YIT & 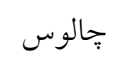 & هنيسك & دوآب جالوس & $19-019$ & \\
\hline 。 & 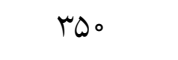 & 4040910 & DrQAN० & جالوس & جالوس & يل يل ذغال & $19-0 Y 1$ & \\
\hline$\pi / \Delta$ & rlo。 & $Y \circ \circ V \circ 9 V$ & Dr9909 & جالوس & زنخوله & يل مرگن & $19-0 v 9$ & \\
\hline 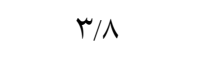 & IVQ。 & ro०qAVI & DYVI9S & جالوس & جالوس & ولى آباد & $19-011$ & \\
\hline 。 & 910 & $Y \circ Y \circ G \mu Y$ & DTYQDI & جالوس & جالوس & آبشار & $19-0 \wedge$ & \\
\hline $14 / 9$ & $10 Y_{0}$ & FOFYYQSF & $\Delta Y \circ T \circ \circ$ & سردآبرود & سردابرود & و والت & $19-010$ & \multirow{6}{*}{$\underset{\xi}{\xi}$} \\
\hline $1 N / 1$ & rIYo & r৭900/ & QQVDIV & هراز & نمارستاق & نمارستاق & $10-0.9$ & \\
\hline $19 / r$ & $9 r_{0}$ & M990YAT & GIFTar & هراز & نمارستاق & ينجاب & $10-011$ & \\
\hline$r M / l$ & 1490 & 40.9919 & OVTVGG & 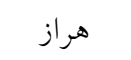 & نور & بلده & $10-01 r$ & \\
\hline$Y Y / Q$ & IYYO & 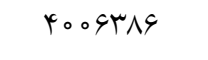 & $909|Y|$ & هراز & 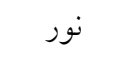 & 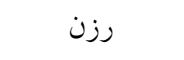 & $10-010$ & \\
\hline $10 / 9$ & 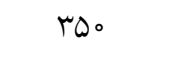 & $\varphi \circ \varphi \circ 910$ & 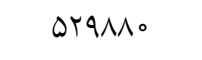 & جالوس & جالوس & يل ذغال & $19-0 Y 1$ & \\
\hline
\end{tabular}

با توجسه بــه اينكــه دادههـاى خـام ورودى شـامل بــارش و

رواناب با واحدها و بزركىهاى متفاوتى نسبت به يكديخرند، از

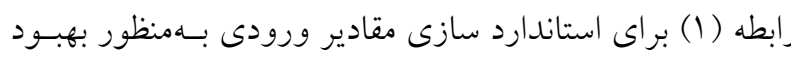
مدلسازى استفاده مىشود.

$\mathrm{X}^{\prime}=\left(\mathrm{X}_{\mathrm{i}}-\overline{\mathrm{X}}\right) / \sigma_{\mathrm{X}}$
يك لايه ورودى متشكل از مجموعسه خـرهــا (در ايـن مطالعـه دادههاى بارش و رواناب) و يك لايه خروجى (يا لايه كوهونن) كه توسط گرههايى كه در شـبكهاى دو بعـدى قـرار گرفتـانـد، است (شكل r). تعداد بهينه واحدهـاى نقشـه برابـر است كه N تعداد بردارهاى ورودى در مجموعه دادهها هستند. 


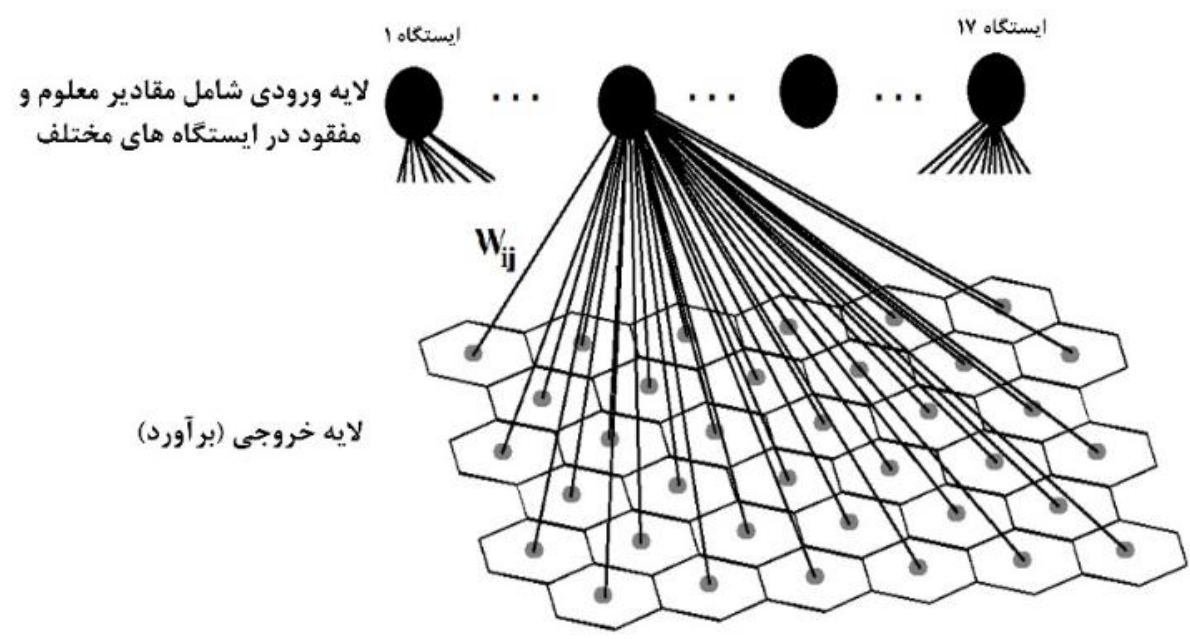

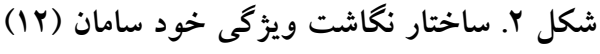

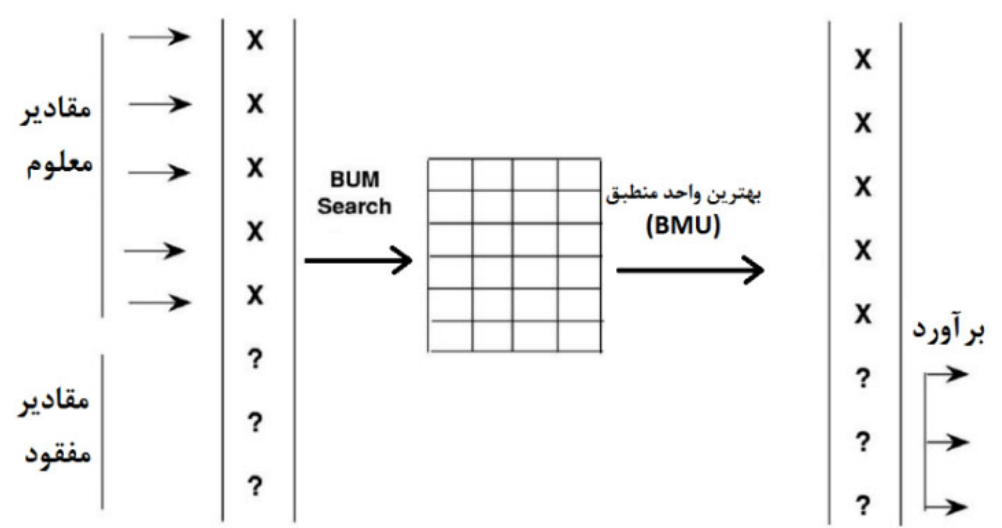

شكل r. يُشبينى مقادير مفقود در بردار ورودى با استفاده از نغاشت خودسامانده (YV)

مىشوند. فرآيند يادكيرى تا زمانى كه معيار توقف (معمولاً زمانى

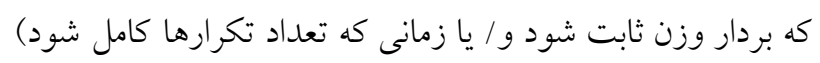

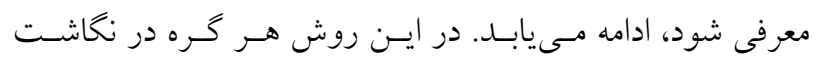

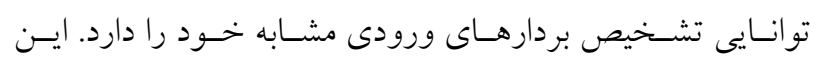

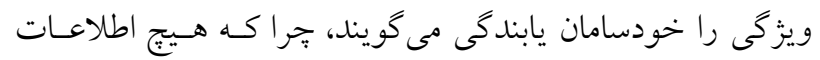

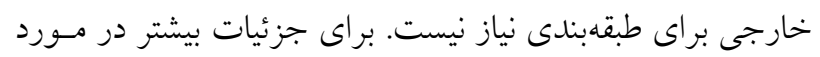
الكوريتم SOM مى SOوان به هايكين (Y) (1) مر اجعه كرد. استفاده از SOM براى بيشبينى، كه هدف اصلى اين مطالعه است در شكل (r) نشان داده شده است. ابتدا، مدل با استفاده از

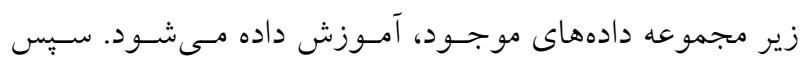

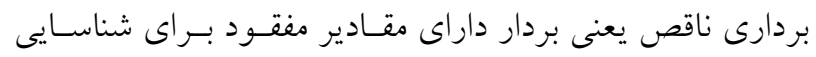
بهترين واحد منطبق (Best Matching Unit)، بر اسـاس فاصـله

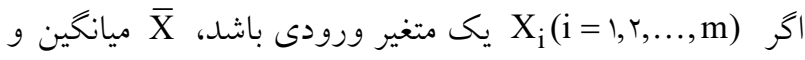
م انحر اف معيار متغير X باعث مى شود تا ميانخين مجموعه دادهها صفر و انحر اف معيـار

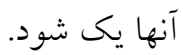
هر گره در لايه ورودى توسط شبكه سينايسى به هـر خـره در

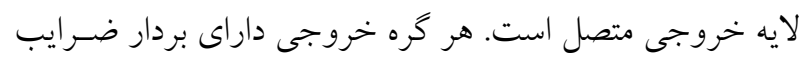

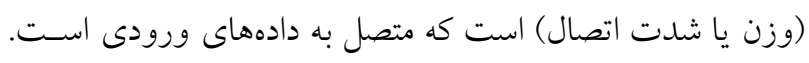
زمانى كه بردارى از ورودى، به SOM وارد شود، كُرهــا در لايسه

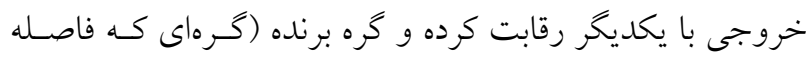
تمامى وزنهايش از بردار ورودىى حداقل است) انتخاب مى شىهود.

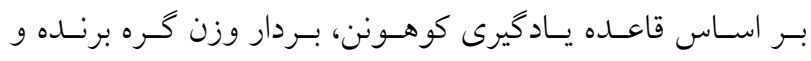

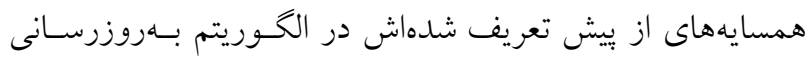


و دبى سنجى مورد بررسى بـهــور هـمزمــان و در سـناريو دوم بهصورت جداكانه بهعنوان ورودىى مدل استفاده شد.

\section{نتايج و بحث}

در اين بخش بهمنظور مقايسه تأثير تركيب ورودىهاى مختلـف در مدل SOM دو سناريو معرفى شد و نتـايج آن بـا اسـتفاده از آمارههاى ارزيابى، كـارايى مـــل مـورد بررسـى و تحليـل قــرار كرفت.

اطلاعات مورد استفاده در سناريو اول در اين مطالعه VIV متغير (تعداد ايستخاههاى اندازهخيرى) وجـود دارد. هر روز، يـك بـردار ورودى منفــد را تشـكيل مسىدهــد. بدينترتيب q49V بردار وجود دارد كه مطابق با تعداد مشاهدات روزانه (بردارهاى كامل و يا ناقص) است. بردارهاى ورودىى بـا داده مفقود يا بدون اطلاعات، در ستونها با علامت NaN (يـك عدد نيست يـا Not a Number) مشـخص شــند. مدلسـازى شبكه عصبى غيرنظارت شونده خودسامانده توسط جعبـه ابـزار در محيط نرمافزار متلب انجام گرفـت. ايسن جعبـه ابـزار SOM توسط توسط آزمايشخاه اطلاعات و علوم كـامييوتر در دانشـخاه هلسينكى گسترش يافته است. بر اسـاس ارتباطـات جنــدمتغيره موجود بين دبى و بارش، تمام دادههـاى متشـكل از V متغيـر، بهاعنوان ورودى آموزش شبكه عصبى مورد استفاده قرار كرفت. اين سناريو كه تمام دادهاى دبىسنجى و بارانسنجى بهصورت يكىجا بـهمنظور تخمسين دادههـاى مفقـود مـورد اسـتفاده قـرار كرفتند، سناريوى اول نام گذارى شد.

اطلاعات مورد استفاده در سناريو دوم در سناريو دوم دادههاى بارش و دادههاى دبى سنجى بهصورت جداكانه بهعنوان ورودى SOM مورد اسـتفاده قـرار كرفـت. بـا استفاده از دو كروه داده مستقل براى آموزش شـبكه، 11 متغيـر

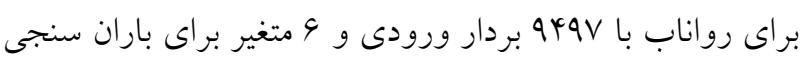

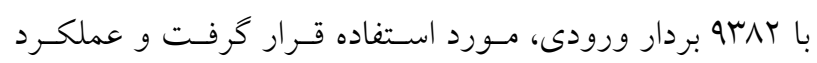

اقليدسى به مدل ارائه مسىشـود. نرونسى كـه بــردار آن بيشـترين مطابقت يا شباهت را با بردار دادههاى ورودى دارد بهعنوان گره مورد نظر بر گزيلده خواهد شد كه بـهـ آن بهتـرين واحـــ انطبـاق يافته (BMU) نيز كفته مىشود. ســـ مقــادير متغيـر مفقـود از مقدار متناظر آن در BMU، در نظر كرفته مى شود.

\section{ارزيابى كارايى مدل}

كارايى مدل در مراحـل آمـوزش و اعتبارسـنجى بــا اسـتفاده از معيارهاى آمارى زير مورد بررسى قرار گرفت.

ضريب تعيسين (Coefficient of determination $\mathrm{R}^{r}$ ) بيـانگر ميـزان احتمـال همبسـتخى ميـان مقـادير مشــاهده شــده و بيشبينى شده است. مقدار R بين صفر و يك متغير اسـت و مقدار R براى بيشبينى مناسب بايد نزديك يك باشد. خطاى مطلق ميانخين (Mean absolute error) براى محاسبه متوسط خطا استفاده شد. همحنجين ريشـه ميـانخين مربعـات خطـا Root Mean Square Error) تفــاوت ميـان مقـدار يِيشبينى شده توسط مـدل و مقـدار واقعى اسـت و بــراى مقايسه خطاهاى بيشبينى توسط يك مجموعه داده است كه در مقايسه با خطاى مطلق ميانخين وزن بيشترى به خطاهاى

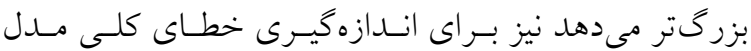
|ستفاده شد.

MAE $=\frac{\sum_{\mathrm{i}=1}^{\mathrm{n}}\left|\mathrm{P}_{\mathrm{i}}-\mathrm{O}_{\mathrm{i}}\right|}{\mathrm{n}}$
$\operatorname{RMSE}=\sqrt{\frac{\sum_{\mathrm{i}=1}^{\mathrm{n}}\left(\mathrm{P}_{\mathrm{i}}-\mathrm{O}_{\mathrm{i}}\right)^{r}}{\mathrm{n}}}$

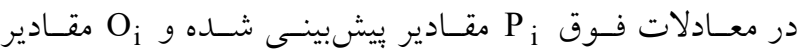
مشاهداتى است.

اطلاعات مورد استفاده بهعنوان ورودى مدل بهمنظور تهيه ورودى مدل تخمين گر دادهاى مفقود، ابتدا دادهها بهصورت ستونى مرتب شدند، بهنحوى كه هر ستون داراى يك

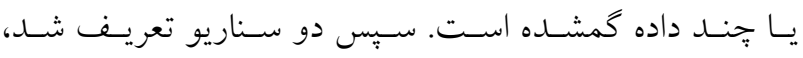
بدينترتيب كه در سناريو اول دادههاى ايستخاههاى بارانسنجى 
جدول r. معيارهاى ارزيابى كارايى مدل در سناريوى اول

\begin{tabular}{|c|c|c|c|c|c|}
\hline خطاى مطلق ميانخين & ريشه ميانخين مربعات خطا & ضريب همبستخى & كد ايستگاه & نام ايستخاه & متغير \\
\hline T/YG & $Y / T_{1}$ &.$/ 94$ & $19-0 Y 1$ & ل يل ذغال & \multirow{11}{*}{ ci } \\
\hline$\circ / V_{1}$ & $1 / T r$ &.$/ 94$ & 19 -OY & كلاردشت & \\
\hline $1 / 99$ & זr/ &.$/ 9 T$ & $10-010$ & ر ت حزن & \\
\hline $0 / 94$ & $1 / 00$ & $\circ / N$ & $10-011$ & ينجاب & \\
\hline.$/ 99$ & $T / \circ V$ & $\circ / \Lambda$ & $19-\circ \wedge \Delta$ & و الت & \\
\hline $1 / r_{0}$ & T/l。 &.$/ 94$ & $10-01 \pi$ & بلده & \\
\hline$\circ / 40$ & $\circ / \Lambda 1$ & $\circ / \Lambda \mathrm{V}$ & $19-019$ & دوآب جالوس & \\
\hline$\circ / T_{1}$ & $0 / \mathbb{E V}$ & $0 / 91$ & $19-01 V$ & دره هريجان & \\
\hline O/TY & - /Qr & $\circ / 19$ & $19-0 \vee 9$ & يل مركن & \\
\hline.$/ 9 \mathrm{~V}$ & $1 / \wedge 1$ & $\circ / \wedge \Delta$ & $19-011$ & ولى آباد & \\
\hline $1 / 44$ & $r / 91$ &.$/ 94$ & $19-0 \wedge r$ & آبشار & \\
\hline$\circ / \mathrm{VV}$ & T/YT & o/AY & $10-0.9$ & نمارستاق & \multirow{6}{*}{$\underset{.}{\xi}$} \\
\hline$\circ / \pi \Delta$ & $1 / Y_{0}$ & ०/^G & $10-011$ & ينجاب & \\
\hline $0 / 90$ & $1 / 19$ & O/AY & $10-014$ & 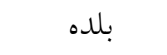 & \\
\hline$\circ / \uparrow \wedge$ & $1 / 4 \wedge$ & $\circ / \wedge \Delta$ & $10-010$ & ر ت حزن & \\
\hline - /Qr & $1 / 49$ & $0 / 19$ & $|9-O Y|$ & يل ذغال & \\
\hline ./or & $1 / 94$ & ०/AG & $19-\circ \wedge 0$ & والت & \\
\hline
\end{tabular}

است. مقادير ضريب همبسـتخى بـراى دادههـاى جريـان بـهنز

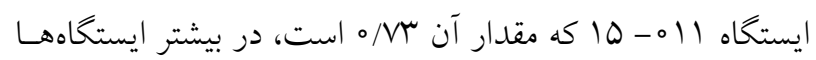

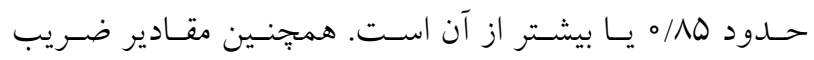

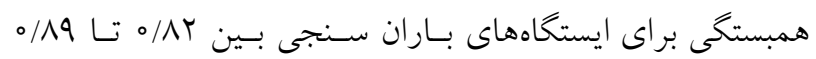

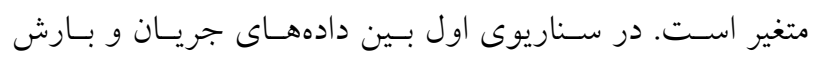

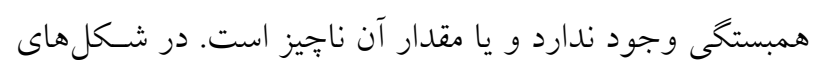

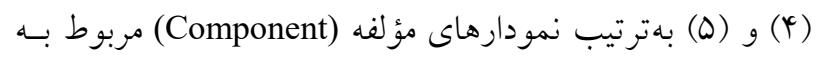

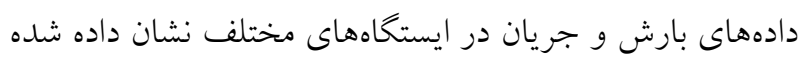

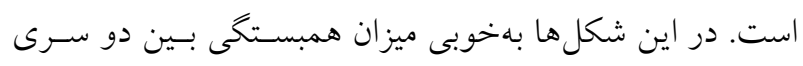

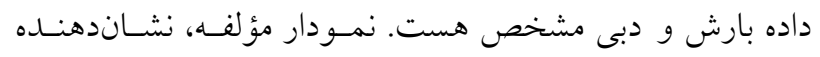

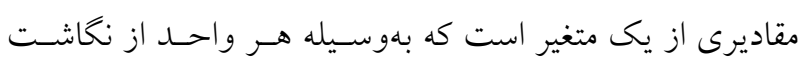

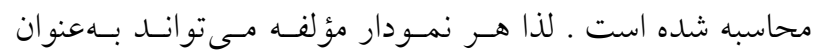
بخشى از SOM فــرض شـود (ه). نمودارهـاى مؤلفـهـ معمـولاً

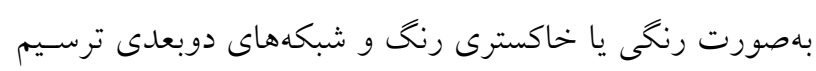

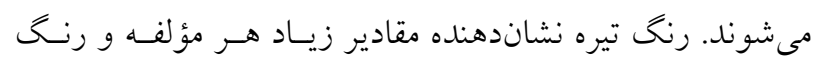

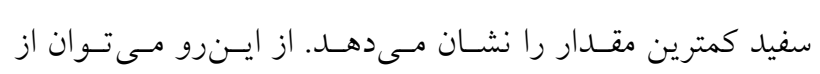

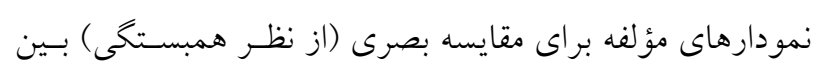

SOM

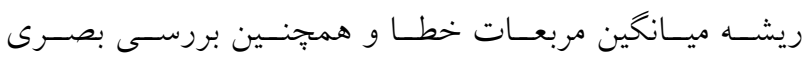

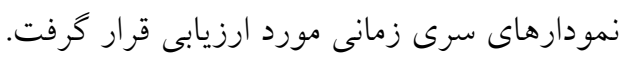

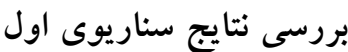

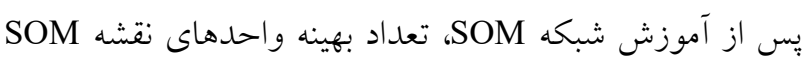

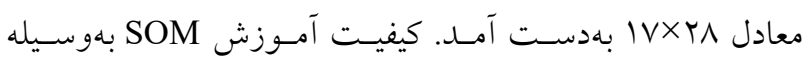
خطـاى تسدريجى ميـانخين كـل ( total average quantization (error و خطـاى تويو گرافيك كـل (total topographic error) محاسبه شد. مقادير نهايى خطاى تدريجى ميانخين كل و خطاى

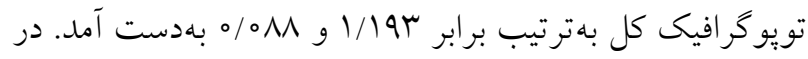

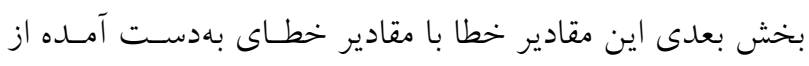
كزينه دوم مقايسه مى شود. عملكرد SOM با با استفاده از ضـرايب

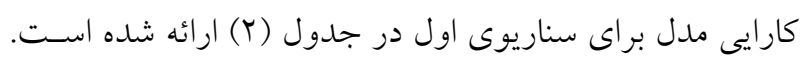

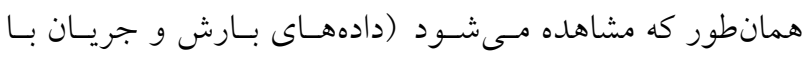

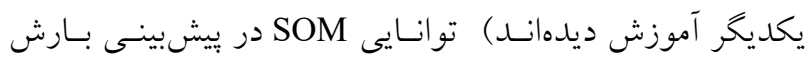

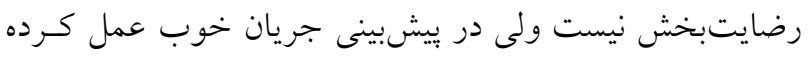



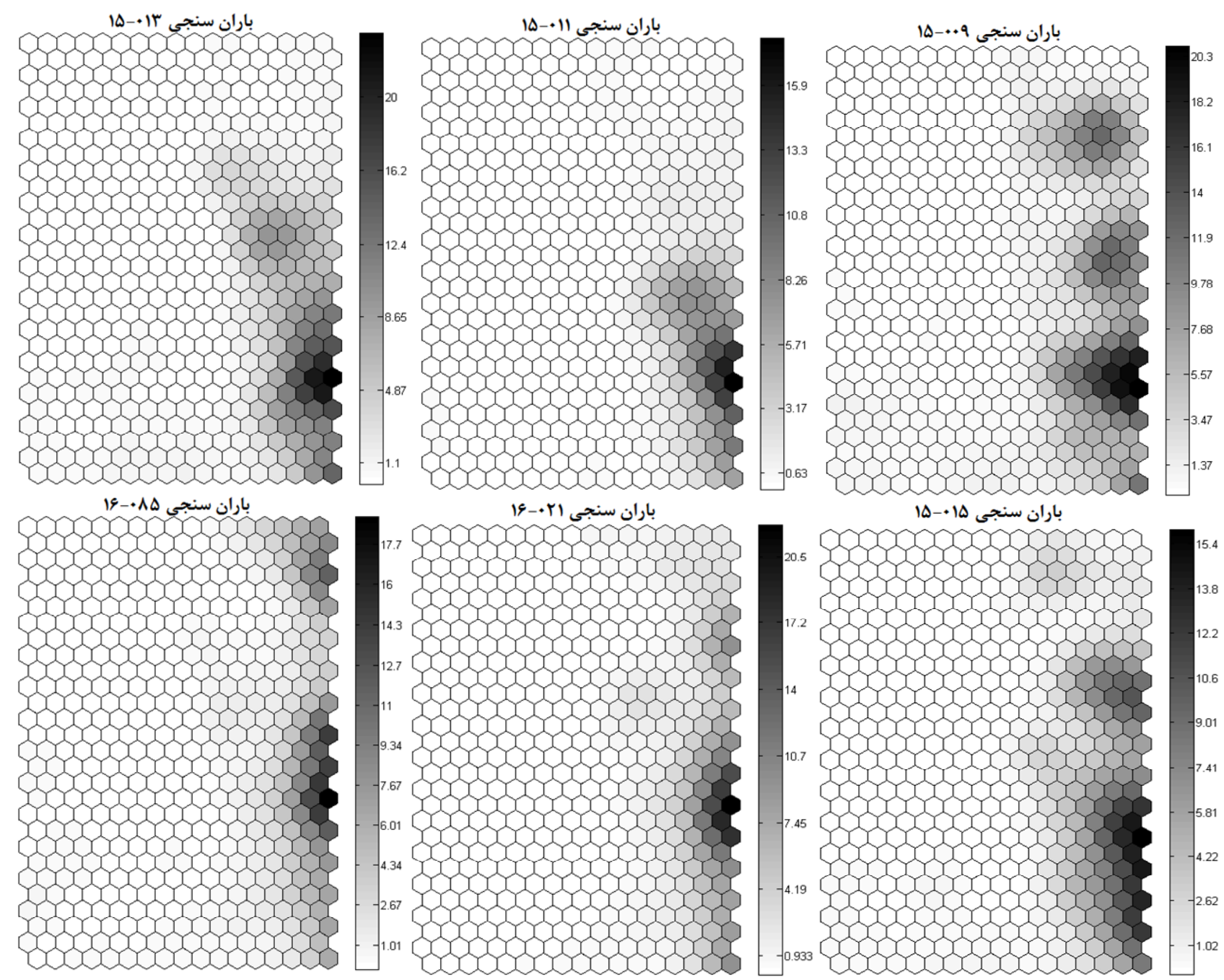

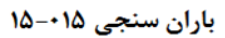

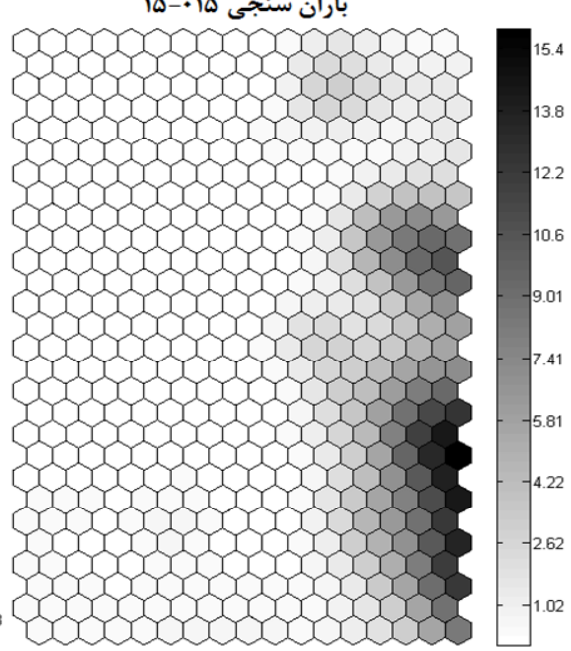

شكل f. نمودار مؤلفههاى مربوط به دادههاى بارش در سناريوى (1)
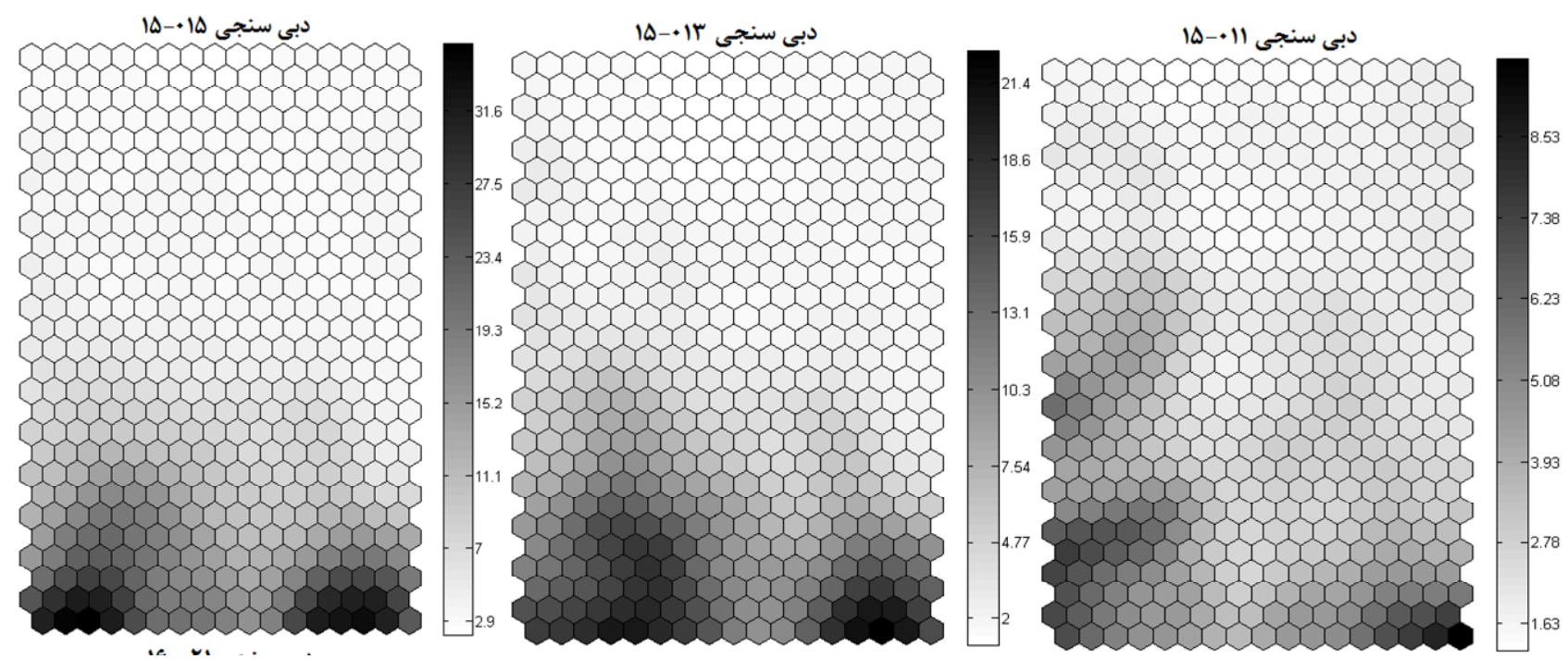

شكل ه. نمودار مؤلفههاى مربوط به دادههاى جريان در سناريوى (1) 
نشريه علوم آب و خاك (علوم و فنون كشاورزى و منابع طبيعى) / سال بيست و سه / ويزُهنامه سيل و فرسايش خاك / زمستان \هـ|

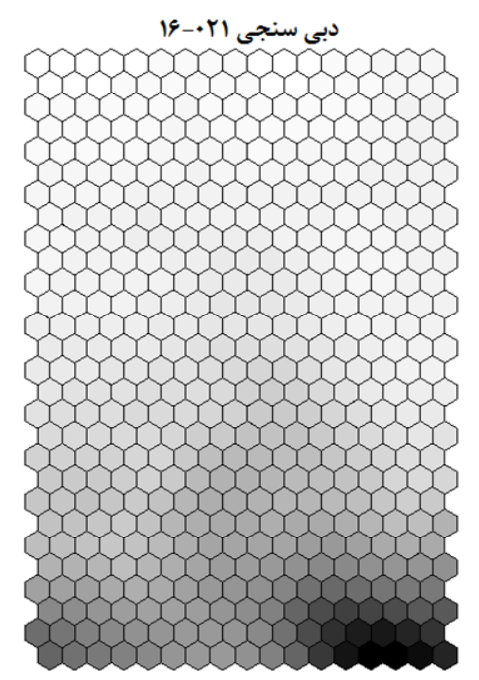

دبي سنجى Dه +-19

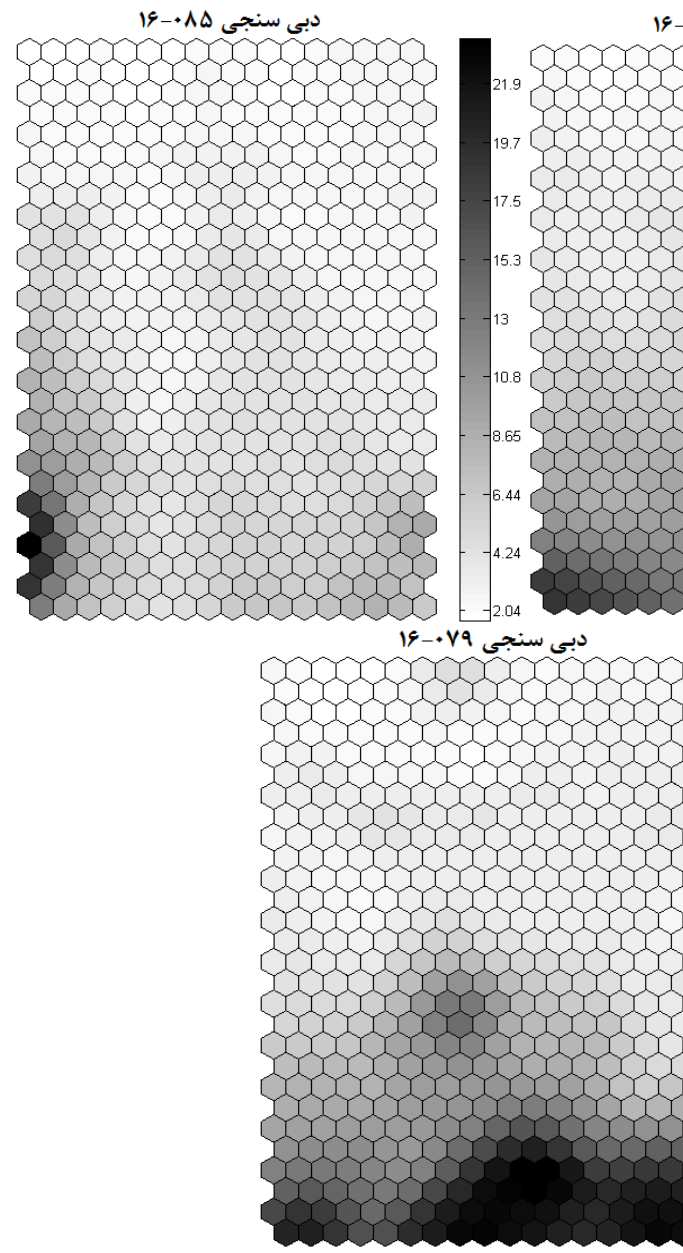

دبي سنجي 19

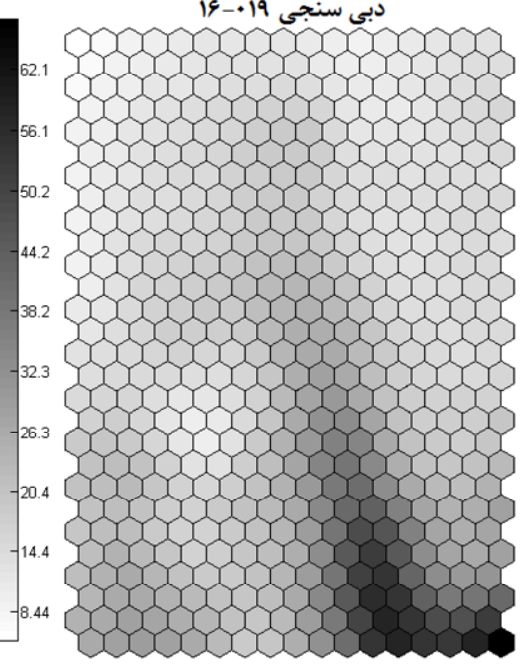

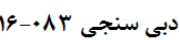

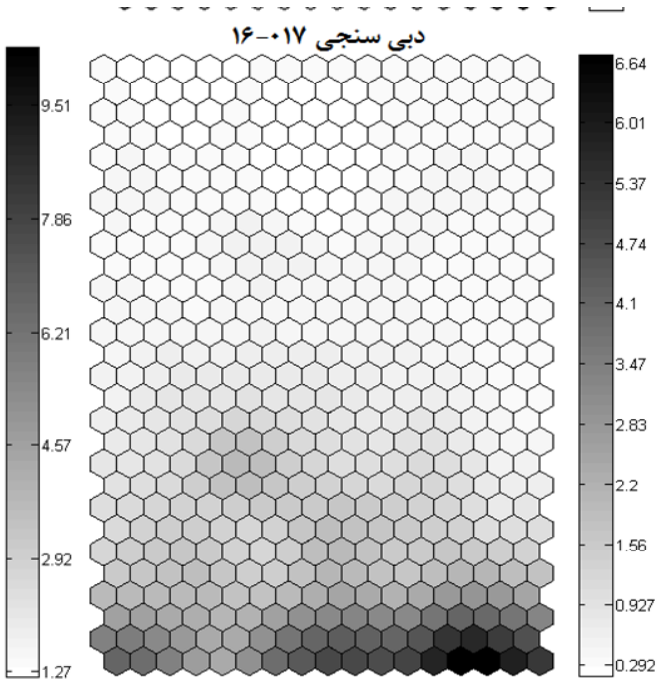

دبى سنحي 19 +-19
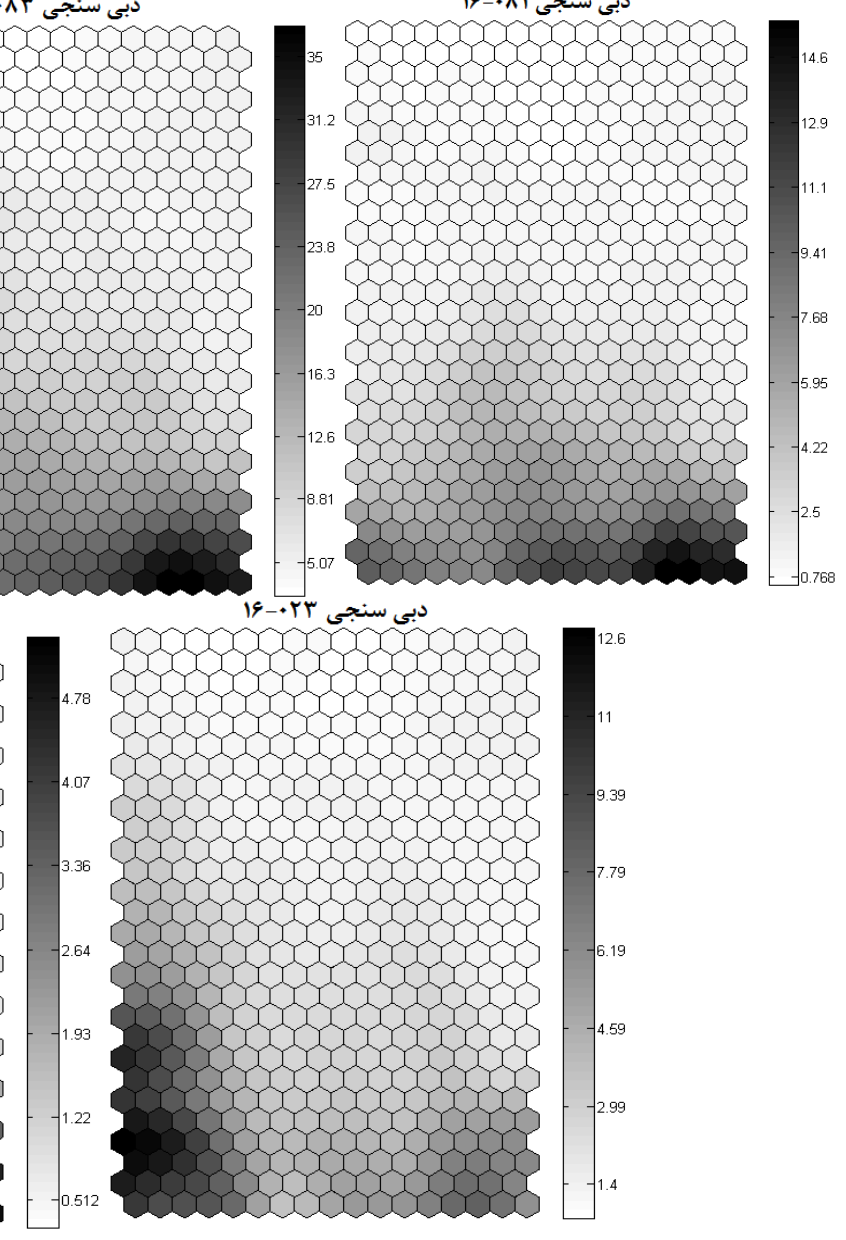

ادامه شكل ه.

ولى اكر اين شيب بر خلاف يكديكر باشد به معناى همبستئى

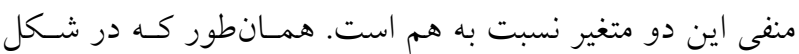

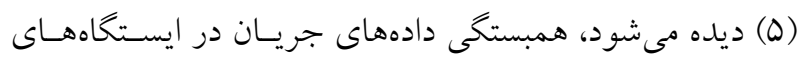

متغيرها استفاده كرد. براى مثال، اكر كراديان يا شيب تغيير رنخ دو نمودار به يكى صورت باشد (بهصورت موازى تغيير كند) بـهـ كئ.

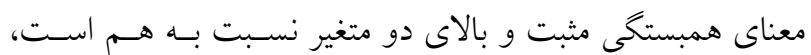


جدول r. معيارهاى ارزيابى كارايى مدل در سناريوى دوم

\begin{tabular}{|c|c|c|c|c|c|}
\hline خطاى مطلق ميانخين & ريشه ميانخين مربعات خطا & ضريب همبستكى & كد ايستخاه & 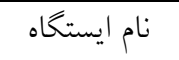 & متغير \\
\hline T/M & $r / 9 T$ &.$/ 90$ & $19-0 Y 1$ & يل ذغال & \multirow{11}{*}{ 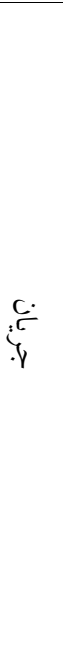 } \\
\hline $0 / 90$ & $1 / 00$ &.$/ 94$ & 19 - & كلاردشت & \\
\hline $1 / 4$ & T/Vq &.$/ 94$ & $10-010$ & رزن & \\
\hline.$/ 01$ & $1 / 4 Y$ & $\circ / \mathrm{VA}$ & $10-011$ & ينجاب & \\
\hline$\circ / V \wedge$ & $1 / 09$ &.$/ 94$ & $19-\circ \wedge 0$ & و والت & \\
\hline $1 / 04$ & $1 / 94$ &.$/ 94$ & $10-01 r$ & 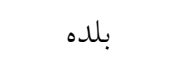 & \\
\hline$\circ / T V$ & $\circ / V Q$ & $\circ / 9 \circ$ & $19-019$ & دوآب جالوس & \\
\hline.$/ 19$ & $0 / 44$ &.$/ 9 T$ & $19-018$ & دره هريجان & \\
\hline$\circ / \Lambda$ &.$/ 40$ &.$/ 94$ & $19-\circ v 9$ & يل مركن & \\
\hline.$/ 90$ & $1 / \mathrm{V}$ & $\circ / \Lambda \Delta$ & $19-0 \wedge 1$ & ولى آباد & \\
\hline $1 / \pi 9$ & $r / T \&$ &.$/ 94$ & $19-\circ \wedge r$ & آبشار & \\
\hline.$/$ MY & $1 / V V$ & $\circ / 19$ & $10-0.9$ & نمارستاق & \multirow{6}{*}{$\underset{. c}{\varepsilon_{*}}$} \\
\hline$\circ / T Q$ & $1 / \circ \wedge$ & $\circ / 19$ & $10-011$ & ينجاب & \\
\hline$\circ / \Gamma \wedge$ & $1 / 9 \pi$ & $\circ / \Lambda \Lambda$ & $10-011$ & بلده & \\
\hline$\circ \mu \circ$ & M & $\circ / 90$ & $10-010$ & 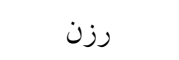 & \\
\hline 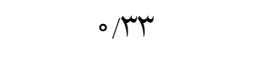 & $1 / T Y$ &.$/ 9 T$ & $19-0 Y 1$ & يل يل ذغال & \\
\hline D & $1 / \pi 9$ &.$/ 91$ & $19-010$ & و والت & \\
\hline
\end{tabular}

بردار وزنهاى خروجى SOM بـراى تخمـين دادههـاى مفقـود

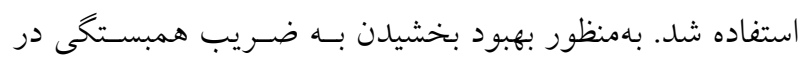

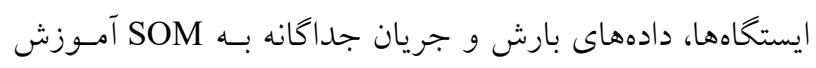

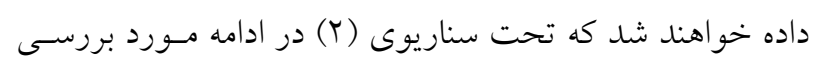

$$
\text { قرار خواهد خرفت. }
$$

\section{بررسى نتايج سناريوى دوم}

در سناريوى دوم جهت بهبود نتايج، خصوصاً در مـورد بـارش،

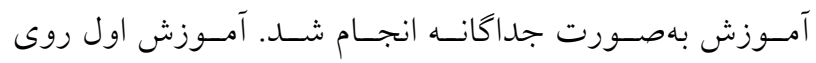
دادهاى جريان و آموزش دوم روى دادههاى بارش كه عملكرد SOM تعداد بهينه واحدهاى نقشه SOM براى ايستخاههاى دبى ســنجى

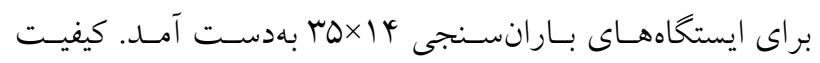
آموزش بر SOM بهوسيله خطاى تدريجى ميانخين كـل و خطساى

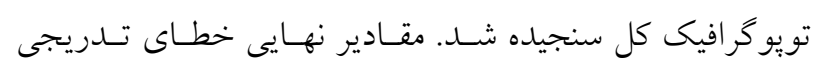

مختلف، مشابه يكديخر هستند. بهعبارت ديخر، بيشترين مقـادير

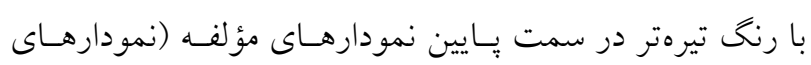

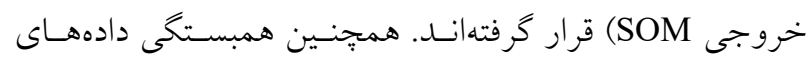
بارش در ايستخاههاى باران سنجى مختلف نيـز مشـابه يكـديخر

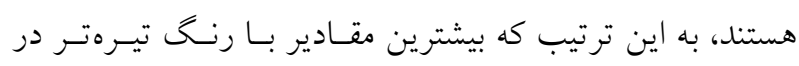
سمت جِّ نمودارهاى مؤلفه (نمودارهاى خروجى SOM) قرار كرفتهاند. اما تفاوت بين نمودارهاى مؤلفه جريان و نمودارهـاى

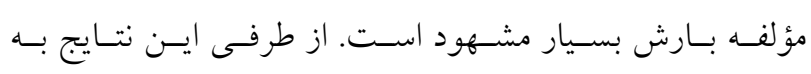
همبستخى ضعيفى بـين جريـان و بـارش نيـز اشـاره دارد. ايسن همبسـتخى اخــه جــه بسـيار ضـعيف اسـت ولـى روى قابليـت يُشبينى SOM تأثير كذاشته است. اين موضـوع قابليـت در خوشهبندى و بصرى كردن نتايج را نشان مىدهد. بـهـعبارت ديخر، الحوريتم SOM مقادير مشابه را در نقشه خروجى كنار هم قرار مىدهد. بعد از آموزش SOM و بهدست آمــدن وزنهـاى نهـايى، از 
كرفت كه توانايى بيشبينى SOM در ارتباط با دادهاى گمشده بارش نيز رضايتبخش است. براى سـناريوى (Y) كـه سـناريو

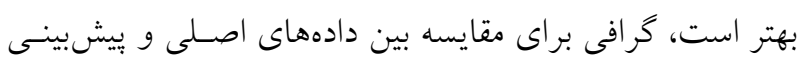
شده توسط SOM رسم شد. اين گراف براى دادههـاى جريـان، نسبت به ايستخاهى كه بيشترين دادهاى گمشده را داشت رسم شد. اين ايستخاه، ايستخاه هيدرومترى يل مركن است كه با كـد

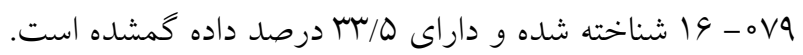
شكل (N) گراف مربوط به مقايسه دادهها اصلى و بيشبينى شده جريان مربوط به ايستخاه يل مرگن با كد

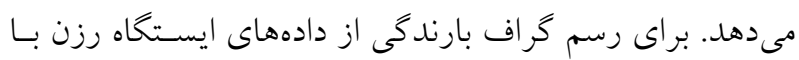

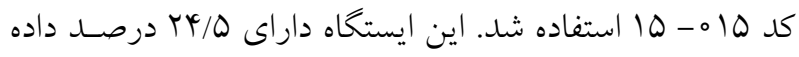
كمشده است كه در بين ايستخاههاى بارانسنجى بيشترين مقدار ديتاى مفقود را دارد. شكل (9) كراف مربوط به مقايسه دادههاى اصلى و بيشبينى شده بارش مربوط بـه ايستـاه رزن را نشـان

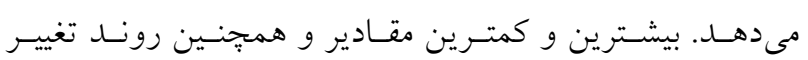
دادههاى بيشبينى شده توسط SOM مطابقت خوبى با دادههـاى

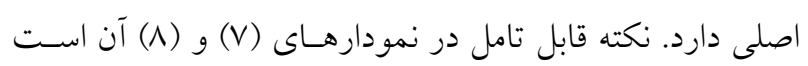

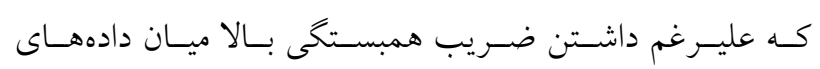
مشاهداتى و بيشبينى شده، الكوريتم SOM مقادير حسداكثرى و

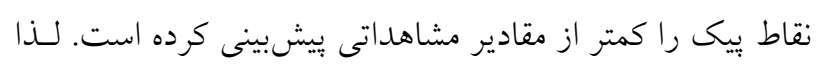

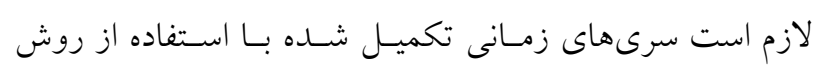
بيشنهادى SOM با احتياط استفاده شود.

\section{نتيجه گيرى}

در حالت كلى SOM ابـزار بسـيار قدرتمنـدى بـراى بيشبينى

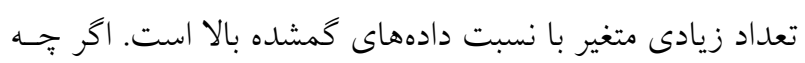

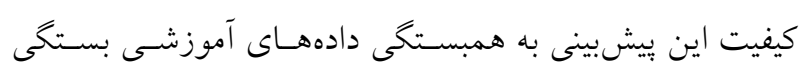
دارد. همجينين اين تحقيق نشان داد كـهـ در ايسن منطقـه قابليـت ييشبينى SOM در مـورد دادههـاى كمشــده جريـان، بهتــر از دادهاى گمشده بارندكى عمل مى كند. يك دليـل محتمـل بـراى

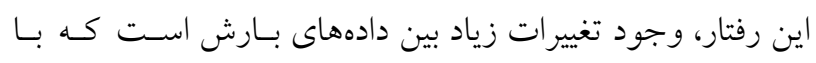

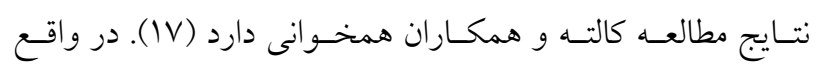

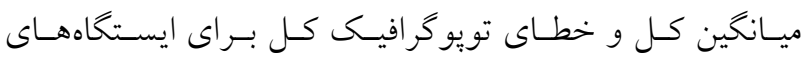

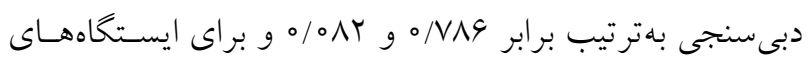

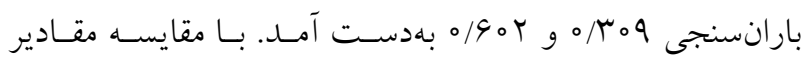
خطاها با بخش (r- r) مشخص است كه ميزان خطاى آموزش مدل كاهش يافته است. بهعبارت ديخر، دقت نتايج بهبـود يافتسه همانطور كه در جدول (r) مشاهده مىشود، ساز كارى بين دادههاى اوليه و دادههاى بيشبينى شده توسط SOM بهبود كلى يافته است. اين موضوع هم براى دادههاى جريـان و هــم بـراى دادههـاى بــارش صـادق اسـت. عملكـــ SOM در بيشبينس دادههاى جريان كه با (Rr) مورد ارزيابى قرار كرفته است. براى

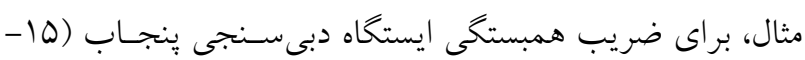

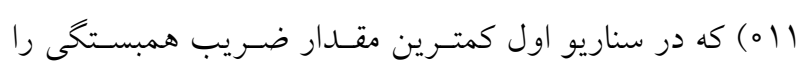

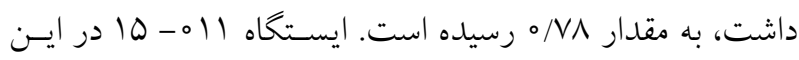
سناريو نيز كمترين مقدار را بهخود اختصاص داد ولى ايسن بـار

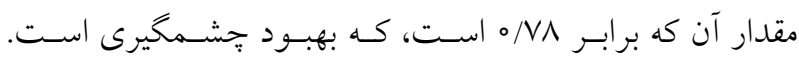

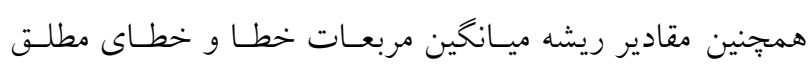

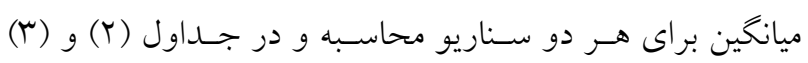
ارائه شده است. همانطور كه مشاهده مىشود كـارايى مــدل در سناريو دوم بهبود جشمخيرى داشته اسـت و مقـادير RMSE و

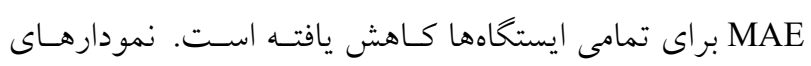
مؤلفه مربوط به دادههاى جريان در شكل (9) ارائه شـده اسـت. همجيجون سناريو اول، در اين سناريو نيـز شـباهت بـين متغيرهـا

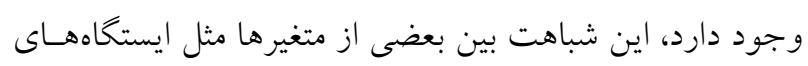
و و 19-0Yl 19-01V، 19-0V9 آشكارتر است. براى ساير متغيرها بيــا كـردن شـباهت تـا ايـن مقدار از نظر بصـرى كـار مشـكلى اسـت ولى بـا وجــود ايسن اختلافات، نتايج SOM در بيشبينى دادههـاى گمشــده جريـان، رضايتبخش است. دامنه تغييرات مقادير (Rr) بـراى دادههـاى

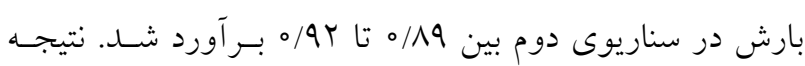
نمودارهاى مؤلفه مربوط به بارش در شكل (V) ديده مسى شــود. در اينجا نيز شباهت هاى زيادى وجـود دارد و مسىتـوان نتيجـهـ 

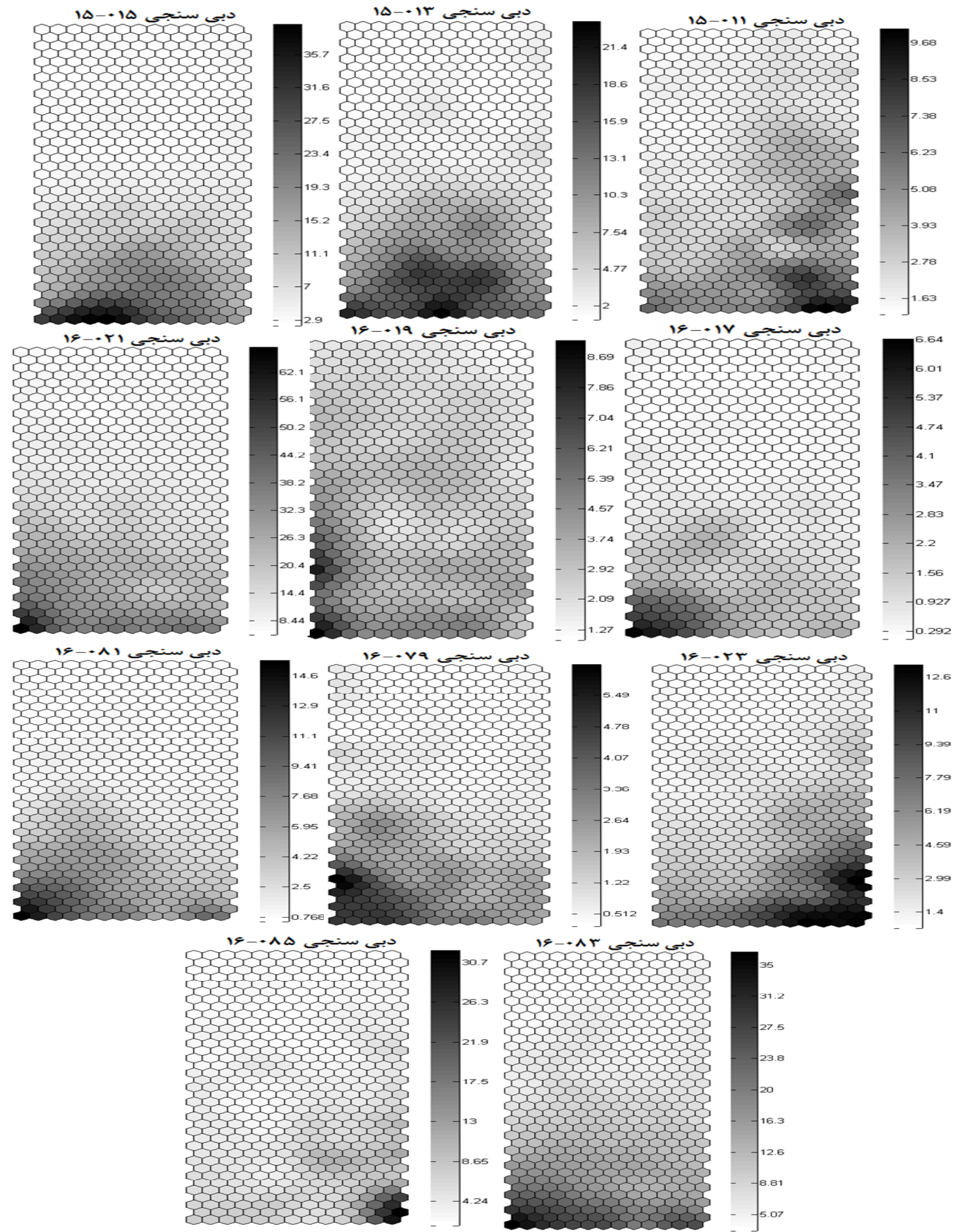

شكل צ. نمودار مؤلفهاى مربوط به دادههاى جريان در سناريوى (Y) 
نشريه علوم آب و خاك (علوم و فنون كشاورزى و منابع طبيعى) / سال بيست و سه / ويزُهنامه سيل و فرسايش خاك / زمستان \هـ|
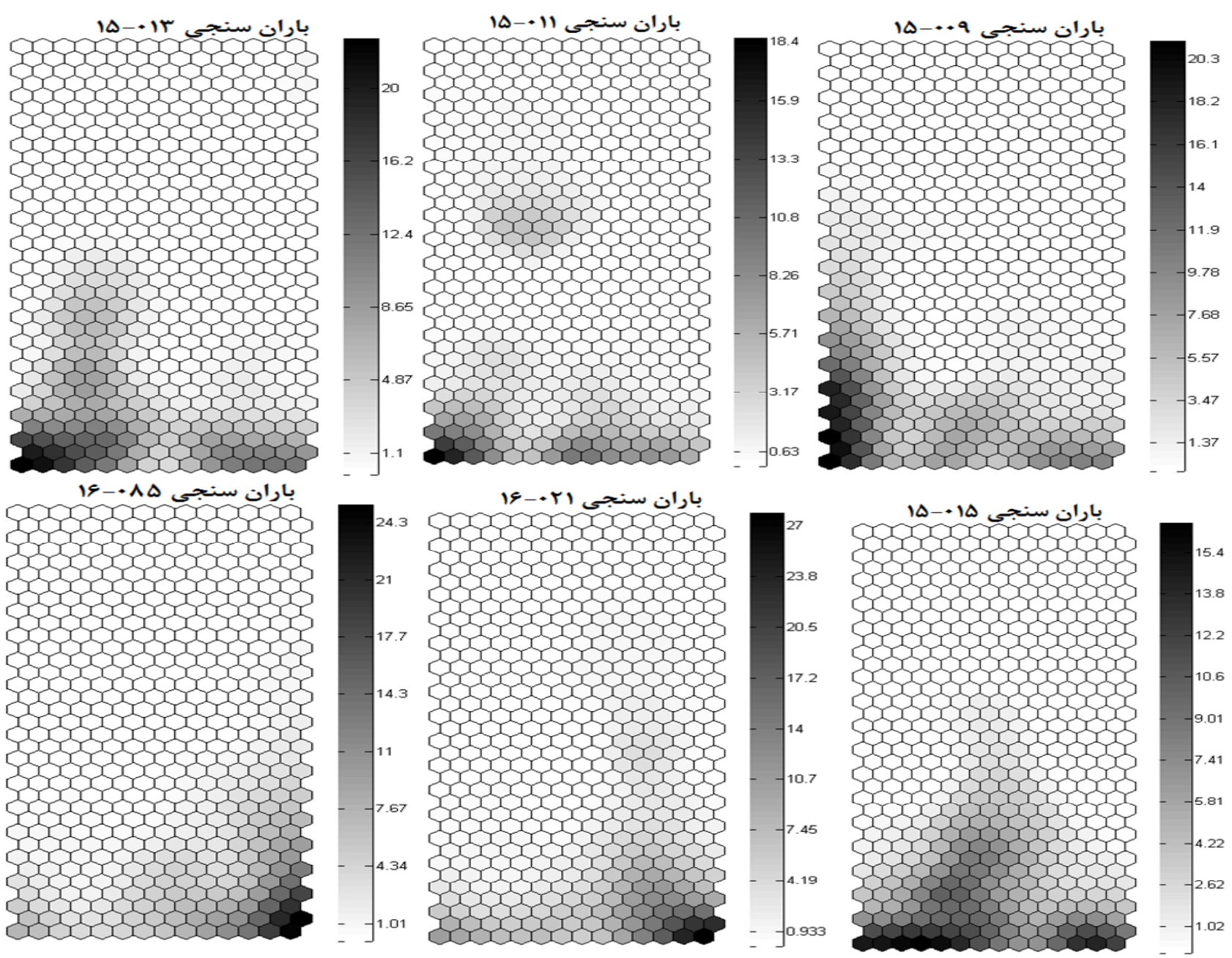

شكل V. نمودار مؤلفهاى مربوط به دادهاى بارش در سناريوى (Y)

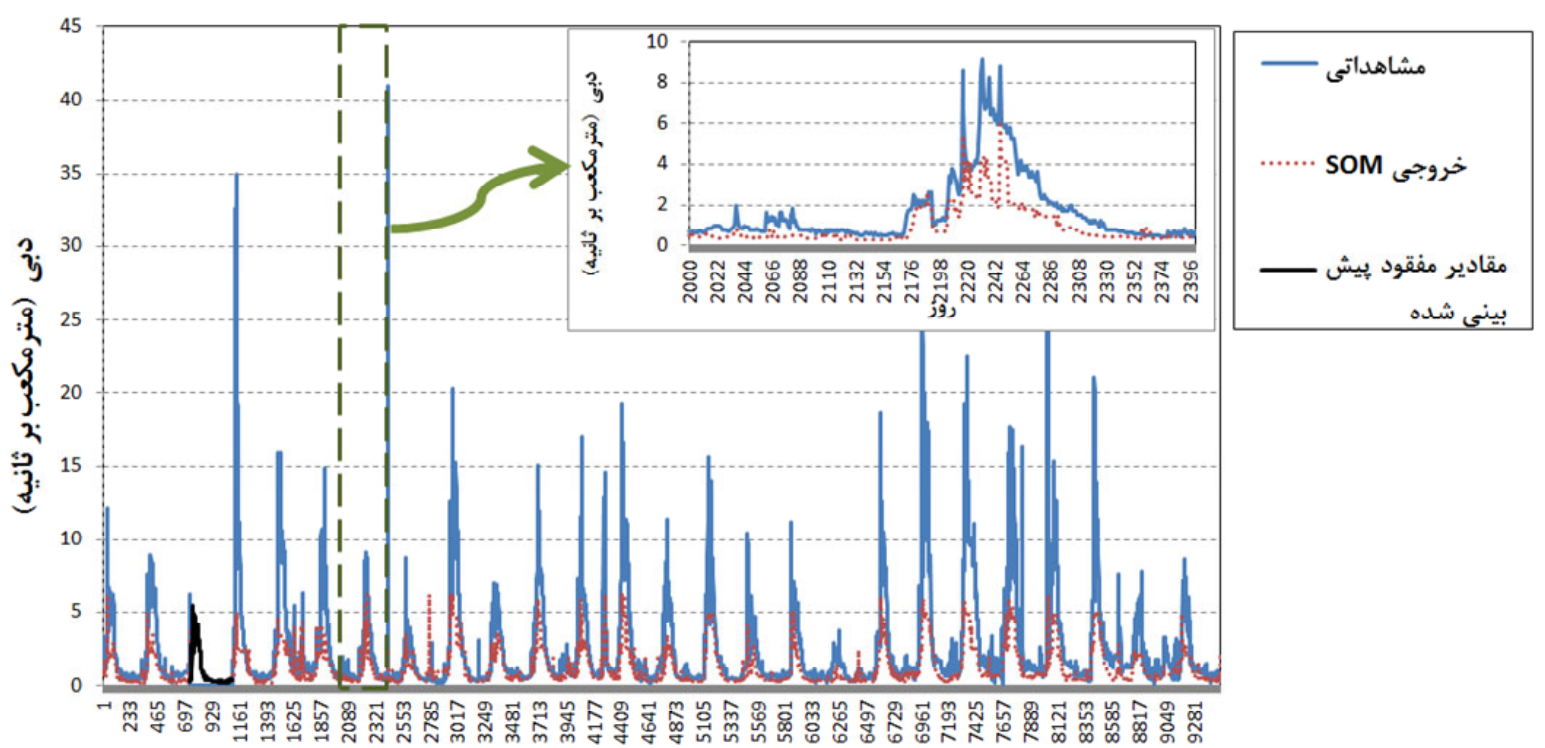

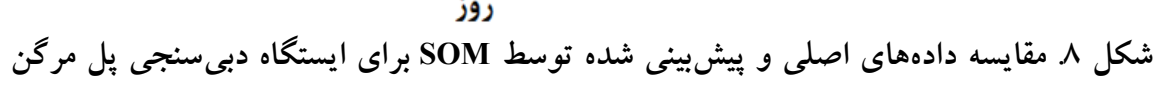




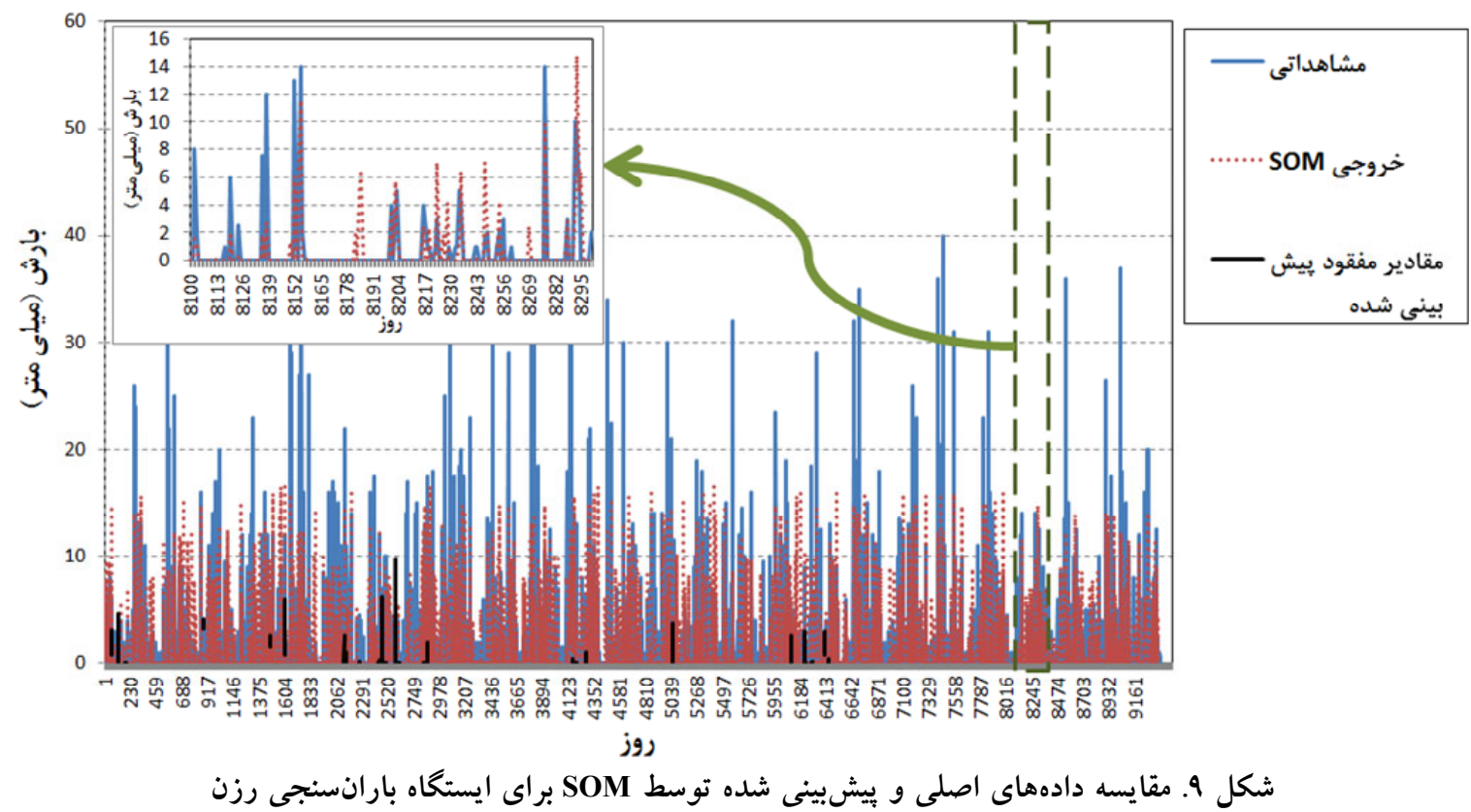

$$
\begin{aligned}
& \text { سرى زمانى تكميل شده جانب احتياط را لحاظ كرد. } \\
& \text { يشي بينى بهتر جريـان توسـط SOM از دو جنبـه بسـيار حسائز }
\end{aligned}
$$

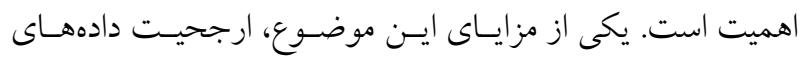

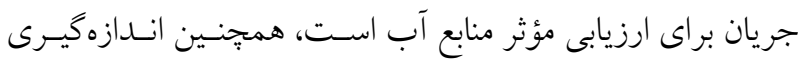

$$
\begin{aligned}
& \text { دادهاى جريان بسيار مشكل و برهزينه است و با اسـتفاده از ايسن } \\
& \text { روش مىتوان سرىهاى زمانى جريان را با دقت بالايى تكميل كرد. }
\end{aligned}
$$$$
\text { كارايى SOM زمانى كه متغيرها تغييرات كمترى نسبت به يكديخر }
$$$$
\text { داشته باشند و يا همبستكى بيشترى داشته باشند، بهبود مىيابد. }
$$$$
\text { نتايج اين تحقيق نشان داد كه الخـوريتم SOM در بيشبينى }
$$$$
\text { نقاط بيك، كم بر آورد (Under estimate) دارد. لــا لازم اسـت }
$$$$
\text { در استفاده از سرىهاى زمانى تكميل شده بـا روش بيشــنهادى }
$$$$
\text { به كاربرد سرى زمانى تكميل شده توجه و در اسـتفاده از SOM }
$$

\section{منابع مورد استفاده}

1. Abdollahi, kh. 2006. Provide a new model and algorithm for the reconstruction of lost data. In: Proceeding of the Third National Conference on Erosion and Sediment, Iran.

2. Abatzoglou, J. T., K. T. Redmond and L. M. Edwards. 2009. Classification of regional climate variability in the state of California. Journal of Applied Meteorology and Climatology 48: 1527-1541.

3. Adeloye, A. J. 1996. An opportunity loss model for estimating value of stream flow data for reservoir planning. Water Resources Management 10(1): 45-79.

4. Adeloye, A. J. 2009. The relative utility of multiple regression and ANN models for rapidly predicting the capacity of water supply reservoirs. Environmental Modelling \& Software 24(10): 1233-1240.

5. Adeloye, A. J. 2011. Reducing the uncertainty associated with water resources planning in a developing country basin with limited runoff data through AI rainfall-runoff modelling. In: Proceedings of the Symposium HS03 - Risk in Water Resources Management, Melbourne, Australia, IAHS 347, pp. 121-126.

6. Adeloye, A. J., R. Rustum. 2012. Self-organising map rainfall-runoff multivariate modelling for runoff reconstruction in inadequately gauged basins. Hydrology Research 43: 603-617.

7. Ben Aissia, M. A., F. Chebana and T. B. M. J. Ouarda. 2017. Multivariate missing data in hydrology - review and applications. Advances in Water Resources 110: 299-309. doi.org/10.1016/j.advwatres.2017.10.002.

8. Dastorani, M. T. 2007. Evaluation of the application of artificial intelligence model for simulation and real-time prediction of flood flow. Journal of Water and Soil Scince 11(40): 27-37.

9. Dastorani, M. T., A. Moghadamnia, J. Piri and M. Rico-Ramirez. 2010. Application of ANN and ANFIS models for reconstructing missing flow data. Environmental Monitoring and Assessment 166: 421-434. 
10. Dinpashoh, Y., D. Jhajharia, A. Fakheri-Fard, V. P. Singh and E. Kahya. 2011. Trends in reference crop evapotranspiration over Iran. Journal of Hydrology 399: 423-433.

11. Farsadnia, F., M. Rostami Kamrood, A. Moghaddam Nia, R. Modarres, M. T. Bray, D. Han and J. Sadatinejad. 2014. Identification of homogeneous regions for regionalization of watersheds by two-level self-organizing feature maps. Journal of Hydrology 509: 387-397.

12. Fei, B. K. L., J. H. P. Eloff, M. S. Olivier and R. H. S. Venter. 2006. The use of self-organizing maps for anomalous behavior detection in a digital investigation. Forensic Science International 162: 33-37.

13. Gyau-Boake, P. and G. A. Schultz. 1994. Filling gaps in runoff time series in West Africa. Hydrological Sciences Journal 39(4): 621-636.

14. Haykin, S. 2003. Neural networks: A comprehensive foundation. Fourth Indian Reprint, Pearson Education, Singapore.

15. Ilunga, M. and D. Stephenson. 2005. Infilling stream flow data using feed-forward back propagation (BP) artificial neural networks: application of standard BP and Pseudo Mac Laurin power series BP techniques. Water SA 31(2): 171-176.

16. Kalteth, A. M. and P. Hjorth. 2009. Imputation of missing values in a precipitation-runoff process database. Hydrology Research 40(4): 420-432.

17. Kalteth, A. M. and R. Berndtsson. 2007. Interpolating monthly precipitation by self-organizing map (SOM) and multilayer perceptron (MLP). Hydrological Sciences Journal 52(2): 305-317.

18. Khalil, M., U. Panu and W. Lennox. 1998. Estimation of missing streamflows: A historical perspective. In: Proceeding of the Annual Conference of the Canadian Society for Civil Engineering. Halifax, Nova Scotia, pp 235246.

19. Kohonen, T. 1982. Self-organized formation of topologically correct feature maps. Biological Cybernetics 43: 5969.

20. Kohonen, T. 2001. Self-Organizing Maps. Springer, Berlin, Germany.

21. Kumambala, P. G. 2010. Sustainability of water resources development for Malawi with particular emphasis on north and central Malawi. PhD Thesis, University of Glassgow.

22. Lookzadeh, S. 2005.Evaluation of several different methods of reconstruction of statistical precipitation discharges in different time scales in central Alborz. MSc. Thesis, Tehran University.

23. Linacre, E. 1992. Climate data and resources - A Reference Guide. Routledge, London and New York.

24. Matinzadeh, M., R. Fattahi, M. Shayannejhad and KH. Abdollahi. 2013. Estimation and reconstruction of maximum 24-hour annual precipitation data using computational model of genetic algorithm and artificial neural networks. Iran Watershed Management Science and Engineering 7(22): 2013.

25. Mwale, F. D., A. J. Adeloye and R. Rustum. 2012 .Infilling of missing rainfall and stream flow data in the Shire River basin, Malawi - A self-organizing map approach. Physics and Chemistry of the Earth 50: 34-43.

26. Naghdi, R., M. Shayannejhad and S. J. Sadatinejhad. 2010. Reconstruction of the runoff data in the Karoon watershed basin by artificial neural networks and comparing it with other methods. Journal of Watershed Management Research 1(1): 59-73.

27. Rustum, R. and A. J. Adeloye. 2007. Replacing outliers and missing values from activated sludge data using Kohonen self-organizing map. Journal of Environmental Engineering 133(9): 909-916.

28. Rustum, R., A. J. Adeloye and M. Scholz. 2008. Applying Kohonen self-organizing map as a software sensor to predict biochemical oxygen demand. Water Environment Research 80(1): 32-40.

29. Sadatinejhad, S. J. 1998. Statistical comparison of precipitation data reconstruction methods in Isfahan province, Master's Degree Thesis, Tarbiat Modarres University.

30. Sadatinejhad, S. J., R. Naghdi and M. Shayannejhad. 2011. Application of Fuzzzy Linear Regression for predicting annual discharge missing data in hydrometric station compared with other conventional methods. Journal of Water and Soil Conservation 17(4): 67-86. 


\title{
Estimation of Missing Daily Precipitation and Runoff Using Self-Organizing Map (A Case Study: Mazandaran Province)
}

\author{
S. Eslami Jamal Abad ${ }^{1}$, A. Sharafati ${ }^{1 *}$, E. Mohammadi Golafshani ${ }^{1}$ \\ and F. Farsadania ${ }^{2}$
}

(Received: December 24-2017 ; Accepted: May 27-2018)

\begin{abstract}
Expert aquatic designers face many problems; among these, in hydrology, defective occurrences in time-series can cause errors in the ultimate results of the study. This more often happens in the regions where the number of hydrometric and rain gauge stations is limited. In addition, assessing, developing and maintaining the use of water resources require accessible long-term and high-quality quality hydrological time-series. Thus, this necessitates correcting the statistical flaws and magnifies the importance of how to deal with the problems in the hydrological analyses. Statistical methods are, currently, used to infill data and statistical gaps. In this study, in order to introduce a multivariate method for estimating the missing data on rainfall and runoff, in a hydrologic homogeneous region in the Mazandaran province, self-organizing map methods were examined under two scenarios and some reliable estimates were obtained. In this regard, the correlation coefficients between the observational data and the model output were calculated for the precipitation data up to 0.92 and up to 0.95 for the runoff data. Therefore, to avoid the reduction of uncertainty caused by the inadequate data in water resource management, this method could be used.
\end{abstract}

Keywords: Unsupervised neural network, Infilling time series, Missing data

1. Civil Engineering Department, Science and Research Branch, Islamic Azad University, Tehran, Iran.

2. Department of Water Engineering, College of Agriculture, Ferdowsi University of Mashhad, Mashhad, Iran.

*: Corresponding Author, Email: asharafati@srbiau.ac.ir 